\title{
Discussion Paper No. 07-087 \\ Does IT Outsourcing Increase Firm Success? \\ An Empirical Assessment using Firm-Level Data
}

Jörg Ohnemus

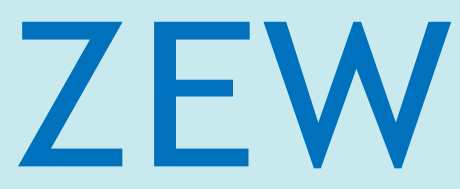

Zentrum für Europäische Wirtschaftsforschung $\mathrm{GmbH}$

Centre for European

Economic Research 


\title{
Discussion Paper No. 07-087 \\ Does IT Outsourcing Increase Firm Success? \\ An Empirical Assessment using Firm-Level Data
}

\author{
Jörg Ohnemus
}

Download this ZEW Discussion Paper from our ftp server:

ftp://ftp.zew.de/pub/zew-docs/dp/dp08005.pdf

Die Discussion Papers dienen einer möglichst schnellen Verbreitung von neueren Forschungsarbeiten des ZEW. Die Beiträge liegen in alleiniger Verantwortung der Autoren und stellen nicht notwendigerweise die Meinung des ZEW dar.

Discussion Papers are intended to make results of ZEW research promptly available to other economists in order to encourage discussion and suggestions for revisions. The authors are solely responsible for the contents which do not necessarily represent the opinion of the ZEW. 


\section{Non-Technical Summary}

The outsourcing of information technology (IT) gained increasing importance during the last years. New data presented by the European Statistical Office (Eurostat) confirm that in 2006, 44 percent of the firms in the European Union were outsourcing at least some of their IT services. Some nations even reached figures well above 70 percent. A question that emerges in this context is, whether firms involved in IT outsourcing show increased performance compared to firms which are not involved in IT outsourcing? Differences in productivity could for example arise, because firms can focus more on their core competencies if they outsource non-core IT services. Furthermore, IT services provided by specialized IT service vendors may be of higher quality and lower cost, due to economies of scale and scope. Therefore, possibly, a competitive advantage arises for firm using IT outsourcing. Moreover, IT outsourcing could also result in an increase of firms' workforce in the medium-term, if firms gain competitive advantages and increase output.

The aim of this paper is to investigate the relationship between information technology outsourcing and firm success, using a comprehensive German firm-level data set. Thereby I focus on two distinct topics: differences in labor productivity between IT outsourcing firms and non-IT outsourcing firms and the effect of IT outsourcing on firms' employment growth rate. The first question is addressed by estimating an endogenous switching regression model for cross sectional data in 2004. This setup accounts for possible interdependence between the IT outsourcing decision of the firm and their labor productivity. Then the effect of IT outsourcing on the growth of the firms' workforce is estimated by an instrumental variable approach. Therefore the growth rate of the firms' number of employees between 1999 and 2003 is used as dependent variable.

The estimation results reveal positive and significant productivity effects of IT outsourcing: First of all, it can be shown that IT outsourcing firms produce more efficiently than firms without IT outsourcing. Second and more importantly, employees working at a computerized workplace are significantly more productive in IT outsourcing firms. This result hints to a complementarity between IT outsourcing and IT intensity of the firm both affecting labor productivity positively. In addition the analysis shows that IT outsourcing, in the medium-term, has a positive effect on firms' employment growth rate. 


\title{
Does IT Outsourcing Increase Firm Success? An Empirical Assessment using Firm-Level Data ${ }^{\dagger}$
}

\author{
Jörg Ohnemus \\ Centre for European Economic Research (ZEW), Mannheim
}

December 2007

\begin{abstract}
Using German firm-level data, an endogenous switching regression model within a production function framework is estimated in order to explore differences in labor productivity between IT outsourcing and non-IT outsourcing firms. This approach takes possible complementarities between IT outsourcing and production input factors into account and further allows IT outsourcing to affect any factor of the production function. Estimation results show that IT outsourcing firms produce more efficiently than non-IT outsourcing firms. Furthermore, they have a significantly larger output elasticity with respect to computer workers. Therefore computer workers and IT outsourcing can be interpreted as complementary factors positively affecting firms' labor productivity. An additional analysis indicates that IT outsourcing, in the medium-term, has a positive effect on firms' employment growth rate.
\end{abstract}

Keywords: IT Outsourcing, Productivity, Endogenous Switching Regression, Employment Growth

JEL-Classification: C21, D24, J21, J24

Address: Centre for European Economic Research (ZEW)

Research Group Information and Communication Technologies

P.O. Box 103443

D-68034 Mannheim

Germany

Phone: $\quad+49-(0) 621-1235-354$

Fax: $\quad+49-(0) 621-1235-4354$ or $+49-(0) 621-1235-333$

E-Mail: ohnemus@zew.de

\footnotetext{
$\dagger$ Financial support by the Landesstiftung Baden-Württemberg foundation is gratefully acknowledged. I would like to thank Irene Bertschek, Françis Laisney, Alexandra Spitz-Oener and the participants of the Brown Bag Seminar at the Humboldt University at Berlin for helpful comments and suggestions. This paper was presented at the DRUID Summer Conference 2007, Kopenhagen, the Conference on the Economics of Information and Communication Technologies 2007, Paris, the Tenth European Workshop on Efficiency and Productivity Analysis (EWEPA X), Lille, and the 34th Conference of the European Association for Research in Industrial Economics (EARIE), Valencia.
} 


\section{Introduction}

Information technology (IT) outsourcing received a lot of attention in public debate during the last couple of years. Indeed, the share of firms active in IT outsourcing is quite substantial. Recent data from Eurostat shows that in 2006, 44 percent of the firms in the European Union were involved in IT outsourcing (see Figure 1 in the Appendix), with some country shares being at 70 percent and above. Big outsourcing deals with Asian or East European companies lately raised fears in highly industrialized nations about negative consequences for the domestic labor market. But so far, most of the IT outsourcing activities in Germany, for example, still take place on a local level. Two recent representative studies for Germany by the ZEW (Centre for European Economic Research) show that in 2004 and 2006, 94 percent of German firms which outsource IT services exclusively cooperate with local IT service providers (ZEW 2005; 2007). Accordingly, only 6 percent of outsourcing firms, which are mainly big manufacturing companies or companies from the Information and Communication Technology (ICT) sector, are active in so called IT offshoring.

During the last one and a half decades, externally provided IT services gained importance as intermediate inputs into the production process of firms. The continuous line in Figure 2 shows this finding for Germany. "Computer and related activities" as a share of total intermediate inputs rose from approximately 0.71 percent in 1991 to 1.53 percent in 2000, with a slight downward trend in the following years. Although these percentage shares do not seem to be quite large, the year 2004 shows a total volume of "computer and related activities" as intermediate input in the production process of more than 28 billion $€$. Since those figures only reflect the outsourced part of the firms' IT services, the overall importance of IT as an input in the production process is substantially higher if the provision of IT services within the firms is taken into account. Subtracting the import share of IT services reveals that although the share of imported intermediate "computer and related activities" input (which reflects IT offshoring by German companies) rose during the period 1991 to 2002, the overall outsourced share to German IT service providers yet experienced a significant increase. This is shown by the lower dashed line in Figure 2 which reflects the import share of "computer and related activities" at total intermediate inputs. This share grew from 0.02 percent to about 0.24 percent in the years 1991 to 2004 . 
Presenting comparable data of the increasing importance of IT outsourcing for the United States, Figure 3 shows an increase in the share of "computer and data processing services" at total intermediate inputs from 1.36 to 1.67 percent for the years 1998 to $2005 .{ }^{1,2}$ Note that a direct comparison of the figures for both countries should be made with caution, due to different IT service definitions. ${ }^{3}$ However, the share of externally provided computer services has increased in both countries since the mid-nineties of the last century.

In the context of IT outsourcing it seems obvious to ask if a firm's performance can be improved through the outsourcing of information technology? In most companies IT does not belong to the core competencies of the firm. Consequently, it would be beneficial for them to source out if they can find an appropriate provider, doing the same work for at least the same costs and quality. This would help the firms' management to concentrate on their core competencies. A result could be a better future performance of firms that source out their IT activities in terms of productivity increases and in terms of their potential to hire new employees for the core business of the firms.

After establishing a positive impact of ICT-investment on firms' productivity in numerous empirical analysis of the last decade, there is still little evidence about the effects of IT outsourcing for the outsourcing firms' economic performance. The aim of this paper is to close this gap by using German firm-level data. The research focuses thereby on the effects of IT outsourcing on labor productivity and the growth rate of firms' workforce (as a measure of firm success). To analyze labor productivity I use cross-sectional data for the year 2004 and apply an endogenous switching regression model (see Maddala, 1983, for further details). This specifications allows to take two different aspects into account: First,

\footnotetext{
${ }^{1}$ Data for the United States is only available since 1998.

${ }^{2}$ Interestingly IT offshoring (measured here as "Computer and data processing services" imports share at total intermediate inputs) for the US is relatively unimportant and not increasing significantly over the observed time span (see lower dashed line in Figure 3).

${ }^{3}$ Figures for Germany are calculated based on Input-Output tables provided by the German Statistical Office (Statistisches Bundesamt), while the data for the USA is provided by the Bureau of Economic Analysis. For the German case, "computer and related activities" correspond to NACE 72. "Computer and data processing services" (for the USA) consist of "information and data processing services" (NAICS 514) and "computer systems design and related services" (NAICS 5415). NAICS is the "North American Industry Classification System". "Computer and related activities" (for Germany) and "Computer and data processing services" (for the USA) are not directly comparable. Nevertheless, the two diagrams give an interesting overview of the increasing importance of IT outsourcing of German and US firms.
} 
there might be a potential simultaneity between labor productivity and IT outsourcing. Causality can go in either direction, IT outsourcing might affect labor productivity or vice versa since firms might outsource their IT tasks to increase productivity. Second, firms are allowed to produce according to different production function regimes depending on their decision to source out basic IT services to external providers. With this flexible representation, the presence of complementarities between IT outsourcing and the input factors can be accounted for. Firms' employment growth rate then is examined by an instrumental variable approach, accounting for the potential endogeneity of IT outsourcing on the firms growth rate.

The empirical results show that employees working at a computerized workplace have a significantly higher contribution to labor productivity in firms involved in IT outsourcing, which suggests that those firms exploit their "ICT-capital" more efficiently. Furthermore, the constant terms in the two regimes, representing multifactor productivity, are also significantly different and higher for IT outsourcing firms. Therefore, it can be said that firms which charge external vendors with taking care of their IT services produce in general more efficiently, compared to their non-IT outsourcing counterparts. The supplementary analysis of the firms' employment growth rate indicates that IT outsourcing has a positive effect on the firms' employment growth.

The rest of the paper is structured as follows: Section 2 gives an overview of some theoretical considerations regarding (IT) outsourcing, followed by a short literature review concerning empirical outsourcing papers. Afterwards, in Section 3, the estimation procedure is introduced, before in Section 4 the data set which is used in the analysis of this paper is presented. Section 5 discusses the estimation results in great detail before Section 6 concludes. 


\section{Background Discussion}

\subsection{Theoretical Perspectives of IT Outsourcing}

To compete in a more and more competitive economic environments, decisions to outsource firm activities are essentially driven by factors related to the costs of production and to productivity. From the perspective of the firm, outsourcing and/or offshoring is therefore seen as a part of its business strategy to reduce cost or improve productivity. For instance, if outsourcing enables a firm to relocate its relatively inefficient production processes to external providers with cheaper and perhaps more efficient production capabilities, the firm can turn its focus to areas where it has a comparative advantage and can expand its output, or even engage in new business activities. Outsourcing of tasks or services that belong to the core activities, on the other side, remains less attractive because of security issues such as the potential lack of control over the processes. The theoretical literature on the firm's decision to produce in-house or outsource through market contracts is extensive and dates back to Coase (1937) and his theory of the firm. ${ }^{4}$

Basically, like every other outsourcing decision, the issue of IT outsourcing is a "make-orbuy" decision of the firm. In the Coasian framework the decision to organize transactions within the firm depends on the relative costs of internal versus external exchange. Within the firm, the entrepreneur may be able to reduce these "transaction costs" by coordinating the activities himself. However, an internal organization causes other kinds of transaction costs, namely problems of information flow, incentives, monitoring, and performance evaluation. In this case, the boundary of the firm is determined by the trade-off, at the margin, between the relative transaction costs of external and internal exchange. In this sense, firm boundaries depend not only on technology, but also on organizational considerations, that is, on the costs and benefits of various contracting alternatives.

In their comprehensive analysis of the literature on Information System (IS) outsourcing, Dibbern et al. (2004) analyze 84 papers published between 1992 and 2000. They find that most of the studies focus on Transaction Cost Theory, Agency Theory or Strategic

\footnotetext{
4 Attention recently also focused on offshoring. Inter alia, Antràs and Helpman (2004), Antràs et al. (2006) and Grossman and Helpman (2002) offer theoretical explanations to this discussion.
} 
Management Theory as a reference framework to explain IS outsourcing. ${ }^{5}$ The main content of those three reference theories is briefly summarized in the following paragraphs.

Transaction Cost Theory states that it is costly to make use of the market (Coase, 1937) and that economic efficiency can be achieved through a comparative analysis of production costs and transaction costs (Williamson, 1975, 1981, 1985). In this framework the transaction is the unit of analysis and a firm's success depends on the efficient management of transactions. The theory is built on two fundamental behavioral assumptions, first, limited rationality and second, opportunistic behavior. Based on the first assumption it is only possible to enter into incomplete contracts. This, however, would be irrelevant if both parties were completely trustworthy (Williamson, 1975, p. 26). It is, however, assumed that in reality the parties behave opportunistically, i.e. they take advantage of opportunities at the expense of others (Williamson, 1981, p. 554). The danger of opportunistic behavior is further assumed to be less likely within a firm than under market coordination, since it can be prevented within a firm by means of the authority principle (hierarchy). The main theoretical argument of the theory is concerned with the conditions under which certain characteristics of the transaction or the object of the transaction would lead to its internal or external governance (or a mixture of both).

The Agency Theory is based on the conceptualization of the firm as a relationship of contracts between principals or stakeholders and agents. The stakeholders are represented by different groups or persons within the firm as well as outside the firm, such as customers, suppliers or shareholders (Jensen and Meckling, 1976, p. 310-311). The basic assumption of the Agency Theory is the existence of information asymmetries and different perceptions of risk between principal and agent as well as uncertainty. The basic argument is that the principal transfers decision rights to the agent. To make sure that the agent behaves in the principal's best interest the latter sets incentives. When calculating the magnitude of these incentives the anticipated costs of controlling the agent are considered. The total cost is the sum of monitoring and bonding including issues such as residual loss. This 'positive Agency Theory' can be distinguished from the normative Principal-

\footnotetext{
${ }^{5}$ Key authors for the Transaction Cost Theory are Coase (1937) and Williamson (1975; 1981; 1985), for the Agency Theory it is Jensen and Meckling (1976) and for Strategic Management Theories there is to mention Chandler (1962), Miles and Snow (1978), Quinn (1980) and Porter (1985).
} 
Agent Theory, which tries to determine optimal contractual relationships based on models that build on restrictive assumptions like perfect information (Jensen and Meckling, 1976).

Strategic Management Theories explain the strategic activities of a firm. Various definitions of strategy can be found in the literature. According to Chandler's definition, strategy is the determinant of the basic long-term goals of an enterprise, and the adoption of courses of action and the allocation of resources necessary for carrying out these goals (Chandler, 1962; Quinn, 1980). Examples of classic Strategic Management Theories are Miles and Snow's (1978) taxonomy of Defenders, Prospectors, and Analyzers, and Porter's (1985) theories of Strategic Advantage.

Along this line of theories, a lot of (empirical) work has been presented in the general context of outsourcing. The following section gives a short overview to this literature, thereby focusing on industry and firm-level results, as well as findings for material and service outsourcing.

\subsection{Review of Empirical Studies}

Quite a lot of empirical papers deal with the aggregate importance of information technology. ${ }^{6}$ But the positive impacts of information technology investments on productivity is also a well-established fact which is documented in several empirical firm-level studies (i.e. Brynjolfsson and Hitt 1996; 2000; 2003, Greenan and Mairesse, 2000, or Hempell, 2005, to mention a few). The literature dealing with outsourcing and/or offshoring is basically focused on the outsourcing of material and service inputs, both on the industry and the firm-level. In this context service inputs mostly include computer services, albeit on a very aggregated level. Comprehensive overviews of this literature are given in Heshmati (2003) and more recently in Olsen (2006). One branch of the literature investigates the differences in productivity growth in manufacturing and service industries, arguing that the outsourcing of services helped to promote productivity growth in the manufacturing sector (e.g. Siegel and Griliches, 1992; Fixler and Siegel, 1999; ten Raa and Wolff, 2001). Amiti and Wei (2006) investigate the effects of offshoring services and material inputs on labor

\footnotetext{
${ }^{6}$ Among others, the works of Oliner and Sichel (2000; 2002), Gordon (2000), Jorgenson (2001), Stiroh (2002) and Jorgenson et al. (2004) should be mentioned.
} 
productivity and total factor productivity (TFP) using industry level data for the United States. They find that service offshoring has a significant positive effect on TFP and that it accounts for up to 13 percent of labor productivity growth over the period 1992 to $2000 .^{7}$

One of the first papers dealing with the impact of service outsourcing on productivity on the firm-level is presented by Abraham and Taylor (1996). They find that firms contract out services to smooth production cycles and benefit from specialization. However, Görzig and Stephan (2002) find that firms tend to overestimate the benefits that came along with the outsourcing of business services, as opposed to material outsourcing. In contrast, the results of Girma and Görg (2004) show that the outsourcing intensity of industrial services in some industries is positively related with labor productivity and total factor productivity growth. For the impacts of offshore outsourcing on productivity, see for example Görg and Hanley (2003; 2004; 2005) and Görg et al. (2005). Most of the literature dealing with IT outsourcing is concerned with identifying factors that have an impact on firms' decision to source out information technology. They mainly draw upon economic theories such as the transaction cost or the production theory. For example Loh and Venkatraman (1992) find that production cost advantages are the main reason for IT outsourcing. But until now there is little empirical evidence about whether IT outsourcing has a significant economic contribution for the outsourcing firm at all. This paper attempts to add to this line of literature by examining the contributions of IT outsourcing to firms' labor productivity.

\footnotetext{
${ }^{7}$ Whereas material offshoring only accounts for 3-6 percent of labor productivity growth during this period.
} 


\section{Methodology}

In order to investigate the impact of IT outsourcing on firm success, two different estimation approaches are applied. Firstly, the productivity effects of IT outsourcing are estimated by an endogenous switching regression model within a production function framework. ${ }^{8}$ Secondly, to take a closer look at the growth rate of the firms' workforce, an instrumental variable approach is used. Both models are described in more detail in the following sections.

\subsection{IT Outsourcing and Productivity}

The endogenous switching model assumes that some unobserved factors affect the IT outsourcing decision and labor productivity simultaneously. In contrast to methods based on instrument variables, the endogenous switching regression allows IT outsourcing to change the entire set of partial productivity elasticities instead of limiting IT outsourcing to act only as a shift parameter in the productivity equation (Bertschek and Kaiser, 2004, p. 395).

The empirical specification assumes that firm $i$ produces according to a Cobb-Douglas production technology. Output $Y_{i}$ is a function of conventional capital $C_{i}$ and an efficient measure of labor $L_{i}^{*}$, which itself depends upon the use of computers in the firm. As for the formulation of efficient labor, I use the simple measure of Greenan and Mairesse (2000), which can be stated as follows:

$$
\begin{aligned}
L_{i}^{*} & =L_{i}^{N C}+\left(1+\gamma_{i}\right) L_{i}^{C} \\
& =\left(L_{i}^{N C}+L_{i}^{C}\right)\left(1+\frac{\gamma_{i} L_{i}^{C}}{L_{i}^{N C}+L_{i}^{C}}\right) \\
& =L_{i}\left(1+\gamma_{i} p_{i}\right)
\end{aligned}
$$

$L_{i}^{C}$ is the number of employees working with a computer and $L_{i}^{N C}$ is the number of those who do not work with a computer. $L_{i}\left(=L_{i}^{N C}+L_{i}^{C}\right)$ refers to the total number of employees in firm $i$. The share of computer users is represented by the parameter $p_{i}\left(=L_{i}^{C} / L_{i}\right)$. Relative labor efficiency between the employees working with a computer and those who

\footnotetext{
${ }^{8}$ See for example Bertschek and Kaiser (2004) and Bertschek et al. (2006) for applications of this model. For further comprehensive details about the endogenous switching regression approach, see Maddala (1983).
} 
work without a computer is measured by $\gamma_{i}$. The production function can be presented as follows:

$$
\begin{aligned}
Y_{i} & =f\left(A_{i}, C_{i}, L_{i}^{*}\right) \\
& =A_{i} K_{i}^{\alpha} L_{i}^{* \beta} .
\end{aligned}
$$

The term $A_{i}$ represents differences in production efficiency that are not related to the input factors and reflects multifactor productivity. The exponents $\alpha$ and $\beta$ denote the output elasticities with respect to capital and efficient labor. Empirically, there are many other factors relevant for the estimation of firms' productivity. Therefore a vector $\boldsymbol{X}_{\boldsymbol{i}}$ with further explanatory variables is added to the model. Inserting Equation (1) into (2), dividing by $L_{i}$, taking logs on both sides and adding an i.i.d. error term denoted by $u_{i}$, labor productivity in $\log$ output per employee $\ln \left(Y_{i} / L_{i}\right)$ results in: ${ }^{9}$

$$
\ln \left(\frac{Y_{i}}{L_{i}}\right)=\ln \left(A_{i}\right)+\alpha \ln \left(C_{i}\right)+(\beta-1) \ln \left(L_{i}\right)+\beta \gamma p_{i}+\boldsymbol{X}_{\boldsymbol{i}} \boldsymbol{\theta}+u_{i} .
$$

In a switching regression context there is a separate production function specified for each of the two groups under consideration:

$$
\begin{aligned}
& \ln \left(\frac{Y_{i}}{L_{i}}\right)_{o}=\ln \left(A_{i, o}\right)+\alpha_{o} \ln \left(C_{i}\right)+\left(\beta_{o}-1\right) \ln \left(L_{i}\right) \cdots \\
& +\beta_{o} \gamma_{o} p_{i}+\boldsymbol{X}_{\boldsymbol{i}} \boldsymbol{\theta}_{\boldsymbol{o}}+u_{i, o} \\
& =\boldsymbol{V}_{\boldsymbol{i}} \boldsymbol{\delta}_{\boldsymbol{o}}+u_{i, o}, \\
& \ln \left(\frac{Y_{i}}{L_{i}}\right)_{n o}=\ln \left(A_{i, n o}\right)+\alpha_{n o} \ln \left(C_{i}\right)+\left(\beta_{n o}-1\right) \ln \left(L_{i}\right) \cdots \\
& +\beta_{n o} \gamma_{n o} p_{i}+\boldsymbol{X}_{\boldsymbol{i}} \boldsymbol{\theta}_{\boldsymbol{n o}}+u_{i, n o} \\
& =\boldsymbol{V}_{\boldsymbol{i}} \boldsymbol{\delta}_{\boldsymbol{n o}}+u_{i, n o} \text {. }
\end{aligned}
$$

If firm $i$ outsources IT activities to an external provider, its labor productivity is given by Equation (4). If no outsourcing of IT activities takes place, labor productivity is given by Equation (5). The subscripts $o$ and no denote the two productivity regimes "outsourcing of IT services" and "no outsourcing of IT services".

\footnotetext{
${ }^{9}$ Therefore the approximation $\ln \left(1+\gamma p_{i}\right) \approx \gamma p_{i}$ is necessary.
} 
The endogenous switching regression approach takes into account that firms with and without IT outsourcing differ in terms of observable and unobservable characteristics. If unobservable factors, which influence the decision to outsource IT services, also have an impact on the firms' productivity, the expected values of the error terms in Equations (4) and (5) are different from zero $\left(E\left[u_{i, o}\right] \neq 0\right.$ and $\left.E\left[u_{i, n o}\right] \neq 0\right)$. Simple OLS estimations would lead to inconsistent results. The selectivity bias can be corrected by first estimating the decision to outsource IT services using external identifying variables and in a second step adjusting the production function by adding a correction term indicating the probability that a certain company does IT outsourcing.

Therefore, it is necessary to analyze which firms are involved in outsourcing activities. The IT outsourcing decision of the firm is positive if the expected gains from outsourcing are bigger than the associated costs. Thus, firm $i$ charges an external vendor with taking care of its IT services if the costs per employee associated with outsourcing $C_{i}$ are smaller than the expected productivity profits resulting from outsourcing. The latent variable

$$
\begin{aligned}
I_{i}^{*} & =a\left[\ln \left(\frac{Y_{i}}{L_{i}}\right)_{o}-\ln \left(\frac{Y_{i}}{L_{i}}\right)_{n o}\right]-C_{i}+\epsilon_{i} \\
& =\boldsymbol{Z}_{\boldsymbol{i}} \boldsymbol{\pi}+\epsilon_{i}
\end{aligned}
$$

represents the difference between the productivity gains (weighted by the term $a$, which denotes the effect of the productivity gains from IT outsourcing on the decision to outsource) and the costs arising from IT outsourcing. The outsourcing decision is unaffected by the productivity differences if $a=0$. However, $I_{i}^{*}$ is not observable. What can be observed is $I_{i}$, which represents the behavior of the firm regarding IT outsourcing. The selection mechanism is as follows:

$$
I_{i}= \begin{cases}1 & \text { if } I_{i}^{*}>0 \\ 0 & \text { if } I_{i}^{*} \leq 0\end{cases}
$$


According to Maddala (1983), if I assume that $\left(u_{i, o}, u_{i, n o}, \epsilon_{i}\right) \sim N(0, \boldsymbol{\Sigma})$ with

$$
\boldsymbol{\Sigma}=\operatorname{cov}\left(u_{o}, u_{n o}, \epsilon\right)=\left(\begin{array}{ccc}
\sigma_{o}^{2} & \sigma_{o, n o} & \sigma_{o, \epsilon} \\
& \sigma_{n o}^{2} & \sigma_{n o, \epsilon} \\
& & \sigma_{\epsilon}^{2}
\end{array}\right)
$$

where $\sigma_{o}^{2}$ and $\sigma_{n o}^{2}$ are variances of the error terms of the two regime equations and $\sigma_{\epsilon}^{2}$ is a variance of the error term in the selection equation. $\sigma_{o, \epsilon}$ is a covariance between the error term of the outsourcing regime, $u_{i, o}$, and the selection equation, $\epsilon_{i}$, and $\sigma_{n o, \epsilon}$ is a covariance for the case of the non-outsourcing regime. The covariance between $u_{i, o}$ and $u_{i, n o}$ is not defined since the two regimes are never observed simultaneously. Since $\boldsymbol{\pi}$ can only be estimated up to a scale factor, it is convenient to assume that $\sigma_{\epsilon}^{2}=1$. Given these assumptions, the expected values of the truncated error terms $\left(u_{i, o} \mid I=1\right)$ and $\left(u_{i, n o} \mid I=0\right)$ are

$$
\begin{aligned}
E\left[u_{i, o} \mid I=1\right] & =E\left[u_{i, o} \mid \epsilon_{i}>-\boldsymbol{Z}_{\boldsymbol{i}} \boldsymbol{\pi}\right] \\
& =\sigma_{o, \epsilon}\left(\frac{\phi\left(\boldsymbol{Z}_{\boldsymbol{i}} \boldsymbol{\pi}\right)}{\Phi\left(\boldsymbol{Z}_{\boldsymbol{i}} \boldsymbol{\pi}\right)}\right) \\
& =\sigma_{o, \epsilon} \lambda_{i, o} \\
E\left[u_{i, n o} \mid I=0\right] & =E\left[u_{i, n o} \mid \epsilon_{i} \leq-\boldsymbol{Z}_{\boldsymbol{i}} \boldsymbol{\pi}\right] \\
& =\sigma_{n o, \epsilon}\left(\frac{-\phi\left(\boldsymbol{Z}_{\boldsymbol{i}} \boldsymbol{\pi}\right)}{1-\Phi\left(\boldsymbol{Z}_{\boldsymbol{i}} \boldsymbol{\pi}\right)}\right) \\
& =\sigma_{n o, \epsilon} \lambda_{i, n o},
\end{aligned}
$$

where $\phi(\cdot)$ and $\Phi(\cdot)$ represent the density and distributional function of the standard normal distribution. The terms $\sigma_{o, \epsilon}$ and $\sigma_{n o, \epsilon}$ measure the covariance between the error terms of the production function and the selection equation. Those conditional expectations can be added as additional explanatory variables to Equations (4) and (5)

$$
\begin{gathered}
\ln \left(\frac{Y_{i}}{L_{i}}\right)_{o}=\boldsymbol{V}_{\boldsymbol{i}} \boldsymbol{\delta}_{\boldsymbol{o}}+\sigma_{o, \epsilon} \lambda_{i, o}+\eta_{i, o} \\
\ln \left(\frac{Y_{i}}{L_{i}}\right)_{n o}=\boldsymbol{V}_{\boldsymbol{i}} \boldsymbol{\delta}_{\boldsymbol{n} \boldsymbol{o}}+\sigma_{n o, \epsilon} \lambda_{i, n o}+\eta_{i, n o},
\end{gathered}
$$


where $\eta_{i, o}$ and $\eta_{i, n o}$ are the new residuals, with zero conditional means.

There are two different possible methods to estimate the endogenous switching regression model. A two-stage approach (see e.g. Lee, 1978), where a probit model of the selection equation is estimated in the first stage and the inverse Mill's ratios $\lambda_{i, o}$ and $\lambda_{i, n o}$ are calculated according to Equations (9) and (10). In the second stage then Equations (11) and (12) are estimated. However, the residuals $\eta_{i, o}$ and $\eta_{i, n o}$ are heteroscedastic (Maddala, 1983, p. 225). Since the variables $\lambda_{i, o}$ and $\lambda_{i, n o}$ have been estimated, the residuals $\eta_{i, o}$ and $\eta_{i, n o}$ cannot be used to calculate the standard errors of the two-stage estimates. Studies applying endogenous switching regression models so far have used the method presented by Maddala (1983, pp. 225-226) for estimating the correct variance-covariance matrix. However, this procedure requires potentially complicated adjustments to derive consistent standard errors (Lee, 1978).

The endogenous switching model can be estimated more efficiently by applying the full information maximum likelihood (FIML) method, where the selection equation and the regime equations are simultaneously estimated. This method yields consistent standard errors. Given the assumption of trivariate normal distribution for the error terms, the logarithmic likelihood function for the system of Equations (4), (5) and (6) is given by:

$$
\begin{aligned}
\ln L=\sum_{i=1}^{N}\left\{I_{i}\right. & {\left[\ln \Phi\left(\frac{\boldsymbol{Z}_{\boldsymbol{i}} \boldsymbol{\pi}+\left(\rho_{o, \epsilon} / \sigma_{o}\right)\left(\ln \left(Y_{i} / L_{i}\right)_{o}-\boldsymbol{V}_{\boldsymbol{i}} \boldsymbol{\delta}_{\boldsymbol{o}}\right)}{\sqrt{1-\rho_{o, \epsilon}^{2}}}\right) \ldots\right.} \\
& \left.-\ln \left(\sqrt{2 \pi} \sigma_{o}\right)-\frac{1}{2}\left(\frac{\ln \left(\frac{Y_{i}}{L_{i}}\right)_{o}-\boldsymbol{V}_{\boldsymbol{i}} \boldsymbol{\delta}_{\boldsymbol{o}}}{\sigma_{o}}\right)^{2}\right] \ldots \\
+\left(1-I_{i}\right) & {\left[\ln \left(1-\Phi\left(\frac{\boldsymbol{Z}_{\boldsymbol{i}} \boldsymbol{\pi}+\left(\rho_{n o, \epsilon} / \sigma_{n o}\right)\left(\ln \left(Y_{i} / L_{i}\right)_{n o}-\boldsymbol{V}_{\boldsymbol{i}} \boldsymbol{\delta}_{\boldsymbol{n} \boldsymbol{o}}\right)}{\sqrt{1-\rho_{n o, \epsilon}^{2}}}\right)\right) \ldots\right.} \\
& \left.\left.-\ln \left(\sqrt{2 \pi} \sigma_{n o}\right)-\frac{1}{2}\left(\frac{\ln \left(\frac{Y_{i}}{L_{i}}\right)_{n o}-\boldsymbol{V}_{\boldsymbol{i}} \boldsymbol{\delta}_{\boldsymbol{n o}}}{\sigma_{n o}}\right)^{2}\right]\right\}
\end{aligned}
$$


where $\Phi$ is the cumulative distribution function of the standard normal distribution, $\rho_{o, \epsilon}=\sigma_{o, \epsilon} / \sigma_{o}$ is the coefficient of correlation between $u_{o}$ and $\epsilon$ (note that by definition $\left.\sigma_{\epsilon}=1\right)$ and $\rho_{n o, \epsilon}=\sigma_{o, \epsilon} / \sigma_{o}$ is the coefficient of correlation between $u_{n o}$ and $\epsilon .{ }^{10}$ The signs of the correlation coefficients $\rho_{o, \epsilon}$ and $\rho_{n o, \epsilon}$ have economic meanings (Fuglie and Bosch, 1995; Maddala, 1983). If $\rho_{o, \epsilon}$ and $\rho_{n o, \epsilon}$ have alternate signs, then firms source out IT services on the basis of their comparative advantage: those who source out have above-average returns from outsourcing and those who decide against outsourcing have above-average returns from non-IT outsourcing. On the other hand, if the coefficients have the same sign, this indicates hierarchical sorting: outsourcing firms have above-average returns regardless of their outsourcing decision, but they are better off outsourcing, whereas non-outsourcing firms have below-average returns in either case, but they are better off not outsourcing.

In a further step firms' labor productivity in the case with IT outsourcing is compared to the (hypothetical) labor productivity that firms would achieve if they did not make use of IT outsourcing. Vice versa, the labor productivity of firms without IT outsourcing is compared to the (hypothetical) labor productivity in the case that the firms make use of IT outsourcing. In order to control for the firms' selection decision, the labor productivity is calculated conditional on the firms' choice whether or not to outsource IT. The estimated productivity differentials for firms that decided to source out can be stated as follows:

$$
\begin{aligned}
P D_{i, o}= & E\left[\ln \left(\frac{Y_{i}}{L_{i}}\right)_{o} \mid \boldsymbol{V}_{\boldsymbol{i}}, I=1\right] \ldots \\
& -E\left[\ln \left(\frac{Y_{i}}{L_{i}}\right)_{n o} \mid \boldsymbol{V}_{\boldsymbol{i}}, I=1\right] \\
= & \boldsymbol{V}_{\boldsymbol{i}}\left(\boldsymbol{\delta}_{\boldsymbol{o}}-\boldsymbol{\delta}_{\boldsymbol{n} \boldsymbol{o}}\right)+\left(\theta_{o}-\theta_{n o}\right) \lambda_{i, o} .
\end{aligned}
$$

The first term of Equation (14) represents the expected labor productivity of firms that do IT outsourcing, the second term represents the expected labor productivity for firms with IT outsourcing in the hypothetical case that they had not chosen to do IT outsourcing. $\lambda_{i, o}=\phi\left(\boldsymbol{Z}_{\boldsymbol{i}} \boldsymbol{\pi}\right) / \Phi\left(\boldsymbol{Z}_{\boldsymbol{i}} \boldsymbol{\pi}\right)$ and $\theta_{o}=\sigma_{o} \rho_{o}, \theta_{n o}=\sigma_{n o} \rho_{n o}$ where $\phi(\cdot)$ and $\Phi(\cdot)$ represent the density and the distribution function of the standard normal distribution.

\footnotetext{
${ }^{10}$ Estimation has been carried out with STATA ${ }^{\circledR}$ and the additional 'movestay' command provided by Lokshin and Sajaia (2004).
} 
The term $\boldsymbol{V}_{\boldsymbol{i}}\left(\boldsymbol{\delta}_{\boldsymbol{o}}-\boldsymbol{\delta}_{\boldsymbol{n} \boldsymbol{o}}\right)$ represents the unconditional expected value of the log-labor productivity differential, depending on the estimated coefficients, i.e. due to varying production elasticities in the two regimes. The second term $\left(\theta_{o}-\theta_{n o}\right) \lambda_{i, o}$ represents the impact of the firms' selection on the use of IT outsourcing where $\lambda_{i, o}$ is the inverse of Mill's ratio. For the opposite case, $\lambda_{i, n o}=-\phi\left(\boldsymbol{Z}_{\boldsymbol{i}} \boldsymbol{\pi}\right) /\left(1-\Phi\left(\boldsymbol{Z}_{\boldsymbol{i}} \boldsymbol{\pi}\right)\right)$ (Bertschek et al., 2006).

\subsection{IT Outsourcing and Firm Growth}

A further part of the empirical analysis is to look at the mid-term impact of IT outsourcing on the growth rate of the firms' workforce. Usually, it should be expected that the workforce of firms involved in outsourcing is declining in the short run, due to the fact that previously provided in-house IT services are now done by external service providers. The jobs related to this in-house production became redundant, consequently leading to a reduction of the workforce. However, the mid-term to long-term effect of IT outsourcing on the size of the workforce and hence on the employment growth rate is not clear, since outsourcing (of non-core IT processes) can increase the competitiveness of the firms, leading to an increased demand, which results in increased production accompanied by an increasing workforce.

In order to analyze this hypothesis, an instrumental variable approach, taking a potential endogeneity of IT outsourcing into account, is formulated:

$$
\ln \left(\frac{\text { labor }^{2003}}{\text { labor }^{1999}}\right)_{i}=\alpha+\beta\left(\text { IT outsourcing }{ }_{i}^{2000}\right)+\boldsymbol{X}_{\boldsymbol{i}} \boldsymbol{\gamma}+u_{i}
$$

where $\ln \left(\text { labor }^{2003} / \text { labor }^{1999}\right)_{i}$ is the logarithmic growth rate of firm $i$ 's workforce, IT outsourcing ${ }_{i}^{2000}$ is a dummy variable indicating if the firm is outsourcing IT services in 2000 and the vector $\boldsymbol{X}_{\boldsymbol{i}}$ contains all the other explanatory variables of employment growth. As in the endogenous switching regression model, Y2K consulting is used as an instrument for IT outsourcing.

Based on Equation (15) two estimations are made: The first specification is rather parsimonious considering the number of employees, the skill structure of the work force and sector specific dummies as well as a location dummy as explanatory variables. In the sec- 
ond specification additional variables are considered. Specifically those variables, which focus on the IT intensity of the firms (number of IT applications, the share of employees working at a computerized workplace, the rate of change of the share of computer workers, the rate of change of the number of IT specialists employed) and on the degree of internationalization (export share and wether the firm has a foreign location/subsidiary). 


\section{Data}

The data set used in this paper results from two computer-aided telephone surveys conducted in 2000 and 2004 by the Centre for European Economic Research (ZEW). The surveys had a special focus on the diffusion and the use of information and communication technologies (ICT) in German companies. Each wave of the data set originally contains detailed information of more than 4,000 firms with five and more employees, stratified by industry affiliation ${ }^{11}$, size class and location of the company (West/East Germany). ${ }^{12}$ Besides detailed information on the use of ICT, the data set contains additional information about total sales, the firms' workforce, the skill structure of the employees, total investments, export shares and various other variables.

To analyze the productivity effects of IT outsourcing, I chose the 2004 data set, which provides a sufficient amount of observations for estimation. Tables 1 and 2 compare industry and size structure of this data set with the values of all German firms in the considered industries and their size classes in $2004 .{ }^{13}$ Due to item-nonresponse the estimation sample decreased to a total of 2,336 observations. ${ }^{14}$ Regarding the share of firms in each industry, large differences can be observed between the sample and the population. Especially retail trade and other business-related services are substantially underrepresented in the sample, whereas other industries are considerably overrepresented (see column 3 and 4 in Table 1). On the other side, if I focus on the share of total sales in each industry compared to total sales in the underlying population, one can see that the estimation sample is representing the population quite well. ${ }^{15}$ Table 2 shows a comparison of the estimation sample and the population by size class. As in the industry comparison above, there is quite a substantial difference regarding the mere number of firms in both

\footnotetext{
${ }^{11}$ For a detailed description of the sectors included in the survey, see Table 15 in the Appendix.

${ }^{12}$ For drawing the original survey sample, the data base of the Verband der Vereine Creditreform (CREDITREFORM), Germany's largest credit rating agency, is used.

13 Note that the sector electronic processing and telecommunication is excluded from the estimation sample, due to the fact that firms providing IT services to other companies are mainly located in this sector.

${ }^{14}$ A check of systematic differences in the anatomy of firms (with respect to firm size, sector affiliation, regional affiliation, investment and the share of employees working mainly at a computerized workplace), that have to be left out due to item-nonresponse, indicates that these firms are missing at random.

${ }^{15}$ While the underrepresentation of retail trade diminished, the sectors wholesale trade and other businessrelated services are still slightly underrepresented.
} 
groups. But again, a look at the sales shares shows that the estimation sample is a good representation of the population by firms' size class.

The numbers of total sales are the only data available from the 2004 survey to measure the firms' output. Since there is no further information on intermediate inputs, using sales in a production function framework might induce an omitted variable bias, since industries that operate at the end of the value chain (i.e. wholesale or retail trade) resort more strongly to intermediate goods than industries operating at an earlier stage of the value chain (Hempell, 2005; Schreyer and Pilat, 2001). To control for those differences, I used data from the German statistical office and calculated the shares of real value added at the NACE two-digit industry level. ${ }^{16}$ The firm-specific values for total sales are then multiplied by those two-digit industry-specific shares.

The survey questionnaire covered the whole range of IT services companies potentially need for running their business, asking further if the firms had partially or fully outsourced each specific activity to an external service provider. The range of the covered activities goes from basic IT services, like hard-and software installation to more sophisticated services such as software programming and IT security. The empirical analysis is restricted to those services that are required in every firm using computer technology in its business operations. ${ }^{17}$ The constructed dummy variable for IT outsourcing takes the value one if a firm outsources at least one of those three basic IT services completely and zero otherwise. ${ }^{18}$

An overview of the IT outsourcing intensity in 2004 by industry affiliation is given in the second and third column of Table 3. A total of more than 39 percent of the firms are involved in basic IT outsourcing. In most of the industries the intensity of outsourcing slightly exceeds the mean value, only the share of outsourcing firms in the electrical

\footnotetext{
16 The online data access of the German Statistical Office (GENESIS) is providing this data, based on National Accounts (Volkswirtschaftliche Gesamtrechnung des Bundes).

${ }^{17}$ In detail, these are the (i) installation of hard-and software, (ii) computer system maintenance and (iii) user assistance and support. The reason to look only at basic IT services is that quite a lot of firms do not need more sophisticated IT services, like e.g. software programming. To account for this fact, one had to differentiate between three groups of companies, IT outsourcing and non-IT outsourcing firms, as well as firms with no need for those IT services. This is circumvent by only looking at basic IT services which are basically needed by all firms.

18 There is quite a strong correlation between the dummy variables of the three basic IT services, which indicates that out of those variables a good indicator for basic IT outsourcing can be constructed.
} 
engineering and the technical services industry is substantially below the mean, with only 23 or 29 percent of these firms outsourcing basic IT services. Figure 4 shows the relative frequencies of IT outsourcing in relation to the size of the firm measured by the logarithm of employees, $\ln ($ employees $)$. Since the outsourcing variable is binary, the relative frequencies are obtained by grouping the variable $\ln ($ employees $)$ into equispaced intervals. The size of the individual dots reflects the number of firms in each group. After a slight increase in the outsourcing intensity with increasing firm size, the frequency drops sharply and continues to fall for the group of firms with $4.25 \leq \ln ($ employees $)<4.75 .{ }^{19}$ There is no clear structure in the data for larger firms (with more than 1,400 employees). At the same time the data set contains only a small proportion of large firms, as indicated by the size of the dots.

Since no data was available to measure the physical capital stock of the firms, I used, as in Bertschek and Kaiser (2004) and Bertschek et al. (2006), gross investment figures as an empirical proxy for the capital stock. This approach could be a potential drawback for this study, but without sufficient panel data at hand, it is not possible to calculate the firms' capital stocks by means of the perpetual inventory method (see for example OECD, 2001). Unfortunately, a couple of firms in the original data set have a missing value for investments or report that they have zero investments. ${ }^{20}$ For the firms reporting zero investments, it seems reasonable to assume that investment is positive but low and was rounded to zero by the interviewee. To adress this problem, the value of investment for firms that report zero investment is set to the 10 percent quantile of their respective industry and size class. The investment value of firms with a missing value is replaced by the median value of their respective industry and size class. ${ }^{21}$

Table 4 and 5 show the descriptive statistics for the 2004 sample, which is used to analyze the productivity effects of IT outsourcing. The first table refers to the total sample, while the second table is divided into IT outsourcing and non-IT outsourcing firms. The quantitative variables output, capital, labor, ${ }^{22}$ labor productivity, share of computer workers

\footnotetext{
19 This range is approximately equivalent to 70-116 employees.

${ }^{20}$ With an econometric specification of the production function in logarithmic values for factor inputs, these firms would have been excluded from the sample.

${ }^{21}$ A total of 414 replacements were made, 110 for zero values and 304 for missing values.

${ }^{22}$ Labor is measured in full-time equivalent terms, therefore part-time employees are considered as a half of a full-time employee.
} 
and the share of exports refer to the year 2003, all the other variables refer to the year 2004. Mean labor productivity (in value added terms) is $€ 113,300$ with the median value being substantially lower at around $€ 58,000$. Mean investment (as a proxy for capital) is $€ 2,435,100$ and the average firm size amounts to 245 employees. In the total sample, the share of computer workers is around 42 percent. Almost 23 percent of the sample firms are located in East Germany. A works council exists in 40 percent of the firms and only a small sub-sample of 14 percent has a foreign subsidiary or a foreign location. The average export share amounts to 17 percent. The skill structure of the work force is represented by university degree and vocational education. The average amount of employees with the highest degree of education being a university degree is 18.7 percent. More than 59 percent of the work force had completed a vocational education. The average firm age is 19 years and the average amount of IT applications (software or internet related computer applications) is 5.4 (on a possible scale from 0 to 10). Y2K consulting is, as I already mentioned in the previous chapter, the identifying variable for IT outsourcing. A total of around 54 percent of firms received consulting support for the Year 2000 problem.

Taking the structure of the estimation model for the productivity effects into account, a differentiated examination of the descriptive statistics for IT outsourcing firms and non-IT outsourcing firms is an apparent procedure which is presented by Table 5. While labor productivity is on average higher for IT outsourcing firms, the reverse is true with regard to capital and labor. Also, the share of computer workers is lower in the regime without IT outsourcing. Interestingly, the variables reflecting the internationalization of the firms (foreign subsidiary and export share) are smaller for IT outsourcing firms which have also less IT applications on average. While the share of unqualified employees in both groups is almost the same, non-IT outsourcing firms show in general a higher share of employees holding a university degree.

While the discussion above focused on the data for estimating the endogenous switching regression model described in detail in Section 3.1, I am going to discuss now the data used for estimating the employment growth model in Section 3.2. The data used for this analysis is a combination of the ICT-surveys conducted in 2000 and 2004. Like the data set of the year 2004, the sample of the 2000 survey originally contains detailed information of more than 4,000 firms stratified by industry affiliation, size class and location (West/East 
Germany). The survey is organized as a panel data set, trying to contact as many firms as possible, which are already in the year 2000 sample. Therefore, more than 1,000 observations are included in both surveys. Matching the data for 2000 and 2004 allows to construct the growth rate of the firms' workforce for the period 1999 to 2003, as well as the change in the share of employees working at a computerized workplace and the change in the number of IT specialists employed by each firm for the period 2000 to $2004 .^{23,24}$ After further observations had to be dropped due to item-nonresponse, the size of the data sets for the two specifications of the firm growth estimation decreased to 910 observations for Specification (I) and 659 observations for Specification (II), respectively.

The explanatory variable reflecting the status for IT outsourcing of the firm is generated from data provided in the 2000 survey. As in the productivity estimation, only the outsourcing of basic IT services is considered in the analysis. ${ }^{25}$ Again, the constructed dummy variable indicating whether a firm is involved in IT outsourcing takes the value one if at least one basic IT task is outsourced to an external provider and zero otherwise. Columns 4 to 7 in Table 3 show the number of firms and the percentage share of IT outsourcing firms for each industry and for both specifications under consideration. ${ }^{26}$ In almost all the industries, the share of firms outsourcing basic IT services is higher in the year 2000 compared to the sample for the year 2004 (see column 2 and 3 of Table 3). Only for technical services (in Specification (II)) and other business-related services industries (in both specifications) the share of IT outsourcing firms is lower in 2000 than in 2004. Wholesale trade reveals the highest share of outsourcing firms with 63 percent for Specification (I) and 66 percent for Specification (II). The least active outsourcing sector in 2000 is the electrical engineering industry with 28 percent (Specification (I)) and the technical services industry with 22 percent (Specification (II)), respectively. There is no

${ }^{23}$ Note that the average number of employees is always measured with regard to the legal year before the survey took place, whereas the number of employees working at a computerized workplace and the number of IT specialists is observed for the point of time when the survey took place.

${ }^{24}$ The number of employees working at a computerized workplace are measured as percentage shares of the total workforce. The growth rate of employees working at a computerized workplace therefore is calculated as follows: [( share of computer employees ${ }^{2004} /$ share of computer employees $\left.\left.^{2000}\right)-1\right] * 100$. Employees specialized in information technology are reported in absolute numbers. Due to the fact that a lot of firms report zero IT specialists in the base year 2000, I calculated a log growth rate adding one to each observation: $\ln \left(\right.$ IT specialist $\left.{ }^{2004}+1\right)-\ln \left(\right.$ IT specialist soo0 $\left.^{201}\right)$.

${ }^{25}$ See footnote 17 for further details.

${ }^{26}$ Again the sector electronic processing and telecommunication is excluded from the sample. For further details see footnote 13 . 
substantial difference in the outsourcing intensities for the different data sets underlying the two different specifications. For Specification (I), Figure 5 shows again the relative frequencies of IT outsourcing in relation to the size of firm size. After an initial increase in the outsourcing intensity with firm size, a peak is reached for the group of firms with $3.25 \leq \ln ($ employees $)<3.75$. For larger firms, a decreasing outsourcing tendency can be observed, although there is again no clear tendency for large firms.

The descriptive statistics for all variables used in the estimation of the employment growth model is presented in Table 6 . The mean value of the employment growth is negative, being slightly lower in Specification (I). Basically, the rest of the comparable variables are almost of identical magnitude in both models. The $\triangle$ standard wages (99-03) measures the increase in standard wages during the period 1999 to 2003. This information is provided by the German Statistical Office on NACE two-digit industry level. Besides the growth variables, all other variables in the two specifications refer to the year 2000 . 


\section{$5 \quad$ Empirical Results}

This section presents the estimation results of the endogenous switching regression model, which analyzes the productivity effects of IT outsourcing. First I will take a closer look at the firms' decision in favor of or against IT outsourcing (selection equation). Then, I will continue with the results of the productivity estimation for both regimes. The second part of this section deals with the estimation results of the instrumental variable approach for the firms' employment growth.

\subsection{Productivity Results}

\subsubsection{Selection Equation}

The estimation results regarding the firms' decision whether or not to become involved in IT outsourcing are presented in Table 8. The estimation of the selection equation includes all variables which will later be also included in the estimation of the productivity equations. Additionally, one instrument variable that explains the IT outsourcing decision, but has no impact on labor productivity, is included for identification. The instrumental variable chosen for this purpose is Y2K consulting. This dummy variable indicates whether a firm resorted on external consultancy for the year 2000 problem (also known as the Y2K problem, the millennium bug, and the Y2K bug). The year 2000 problem was the result of a practice in early computer program design that caused some date-related processes to operate incorrectly in terms of dates and times on January 1, 2000 and afterwards. Since computer technology is widely used in companies, virtually all firms were equally confronted with the threat of the year 2000 problem. The final decision to use consulting services depended upon the managements' assessment of how seriously the Y2K problem would affect the firms' normal workflow. This valuation of the year 2000 problems seems unrelated to firms' productivity in 2004. On the other hand, firms that were already engaged in the "outsourcing" of the Y2K problem are more experienced in the use of external help in solving their IT problems and therefore are more inclined to outsource IT activities.

Table 8 contains the estimation results of the selection equation. Besides the identifying variable $Y 2 K$ consulting, the following variables are assumed to have an effect on the IT outsourcing decision: 
- works council: A works council is regarded as having a negative effect on the IT outsourcing decision, since it can be presumed that a works council is always strongly against the outsourcing of formerly in-house production to an external provider. If firms source out substantial parts of their in-house production, a works council itself would loose influence within the firm. Further, long negotiations with the works council to achieve an agreement about outsourcing will increase the total costs of the outsourcing process and therefore hinder IT outsourcing.

- export share: Firms with higher exporting shares are more exposed to international market pressure compared to firms that are only active at home, because they face worldwide competition. Those firms are used to adjust more quickly to changes in the market environment and therefore, the (adjustment) costs of IT outsourcing are assumed to be lower for those firms resulting in a positive effect on the IT outsourcing decision.

- foreign subsidiary: A similar argument holds for firms with a foreign subsidiary/location. Again, these firms are more confronted with international competition, resulting in smaller adjustment cost for the implementation of IT outsourcing. Furthermore, multinational firms are usually presumed to employ better technologies than domestic firms (Markusen, 1995) which makes IT outsourcing even more favorable. On the other hand, firms with a foreign subsidiary may have the possibility or are even forced to use the IT department of the group ${ }^{27}$ (Bertschek and Müller, 2006). As a consequence, the expected sign of the effect depends upon the prevailing argument.

- firm age: For older firms the cost of implementing IT and reorganizing the production process is probably more expensive than for younger firms. According to Christensen and Rosenbloom (1995) younger firms are more flexible. Thus, they are more likely to adopt a new technology. Following this argument, younger firms might be more inclined to adopt a new business model (which in our case is IT outsourcing to an external service provider).

\footnotetext{
${ }^{27}$ Note that IT outsourcing within a group of companies is not regarded as external outsourcing.
} 
- IT applications: The number of software and internet related applications used by the firm is supposed to have a negative effect on outsourcing. It is reasonable to assume that firms that use more IT applications have a more complex IT infrastructure, which can be better controlled by internal IT specialists than by an external provider. Furthermore, in firms with many IT applications the IT infrastructure can be seen as an element of the firms core competencies. They rely heavily on a perfect functioning of their applications in the production process. A decision to outsource core competencies is rather unlikely.

To make the model applicable, the identification variable and all further explanatory restrictions have to be significant. ${ }^{28}$ From Table 8 it can be concluded that $Y 2 K$ consulting is positive and strongly significant for the outsourcing decision. Albeit the effects of the other explanatory restrictions are not individually significant (besides a weakly significant negative effect of foreign subsidiary). As one can see in Table 10, the Wald statistic for joint significance of the set of other explanatory variables (without the identifying restriction $)$ is highly significant $\left(\chi^{2}=30.81 ; p\right.$-value $\left.=0.0210\right)$. Altogether this suggests that the chosen exclusion restrictions are valid, hence the entire model is valid, too.

A closer look on the individual coefficients shows that the existence of firm locations abroad has a significant negative effect on IT outsourcing. This could be explained by the better availability of IT resources that is better within a group of companies. ${ }^{29}$ There are no individually significant effects observable for the other identifying restrictions. For the factor inputs capital and labor the partial coefficients are both negative and in the case of labor also highly significant. This makes sense, since larger firms can make use of economics of scale in running their own IT department. ${ }^{30}$ Firms with a higher share of computer workers are also much less likelier to make IT outsourcing. A higher firm IT intensity (measured in the share of employees working mainly at a computerized workplace) suggests less outsourcing probability. This result can be explained by the fact that the IT in those firms belongs to their core tasks for which outsourcing is

\footnotetext{
${ }^{28}$ For further details, see also Section 3.1.

${ }^{29}$ Note that this kind of sharing IT resources would not fall under our definition of IT outsourcing.

${ }^{30}$ Remember that the descriptive analysis showed a decreasing tendency in IT outsourcing with increasing size of the firms.
} 
not preferable. ${ }^{31}$ A test for joint significance of the entire selection equation is highly significant $\left(\chi^{2}=273.34 ; p\right.$-value $=0.0000$; see Table 10), indicating that the decision to source out IT services is influenced by productivity differences.

\subsubsection{Productivity Equations}

The estimation results of the two regime equations - with IT outsourcing and without IT outsourcing - which are included in the endogenous switching regression model are presented in Table 7. In line with the model described in Section 3.1, the dependent variable labor productivity, as well as the variables for the factor inputs capital and labor are transformed into their logarithmic values for estimation. To compare the coefficients of the two firm-regimes, Wald tests for identity of the coefficients are carried out. The results are shown in Table 9.

Table 7 also contains the correlation coefficients $\left(\rho_{o, \epsilon}\right.$ and $\left.\rho_{n o, \epsilon}\right)$ between the error term of the IT outsourcing selection equation and the labor productivity equations for IT outsourcing firms and non-IT outsourcing firms, respectively. To check wether the IT outsourcing decision is endogenous, one has to test if $\rho_{o, \epsilon}$ and $\rho_{n o, \epsilon}$ are statistically different from zero. If $\rho_{o, \epsilon}$ and $\rho_{n o, \epsilon} 0$ are zero, then the selection into the IT outsourcing regime is exogenous, therefore it would not be necessary to model and include a selection equation to estimate the impact of IT outsourcing on labor productivity. As can be easily seen, the two correlation coefficients are both negative and individually significant. Further, specification tests confirm that these coefficients are also jointly statistically significant (see Table 10, last row). Thus, IT outsourcing can not be treated as truly exogenous and it is necessary to account for selectivity in each of the regime equations. Since both correlation coefficients are negative, this implies that in the outsourcing regime firms with a higher probability of IT outsourcing tend to make smaller productivity gains when they are involved in IT outsourcing. In the non outsourcing regime firms with a higher propensity to outsource would make productivity gains even if they do not actually outsource. ${ }^{32}$ If one doesn't account for unobserved heterogeneity, one would overestimate

\footnotetext{
31 A significantly negative effect is also present for the share of employees with university degree. Firms located in East Germany are more likely to source out their IT.

${ }^{32}$ Note that the inverse Mill's ratio $-\left[\phi\left(\boldsymbol{Z}_{\boldsymbol{i}} \boldsymbol{\pi}\right) /\left(1-\Phi\left(\boldsymbol{Z}_{\boldsymbol{i}} \boldsymbol{\pi}\right)\right)\right]$ is always negative and the estimated coefficient $\rho_{n o, \epsilon}$ is also negative. Therefore, the resulting effect is positive.
} 
the labor productivity of IT outsourcing firms. On the other side, without accounting for unobserved heterogeneity an underestimation of labor productivity for non-IT outsourcing firms would be the case.

As can be seen in Table 7, there is a highly significant and positive effect with regard to the two factor inputs capital and labor, and the share of computer workers on labor productivity in both regimes. ${ }^{33}$ The partial elasticities for capital and labor are slightly higher in the regime without outsourcing activities but according to the results in Table 9, identity cannot be rejected at the usual significance levels. For the share of computer workers, the estimated coefficients are both highly significant, being substantially higher in the IT outsourcing case. ${ }^{34}$ The calculation of the partial output elasticities ${ }^{35}$ and their comparison via Wald-tests results in significant differences of those elasticities. In addition, the value of the elasticity in the outsourcing case is substantially higher. It seems that firms involved in IT outsourcing can use their employees working at a computerized workplace more efficiently. The share of computer workers and IT outsourcing can be interpreted as complementary factors which positively affect firms' labor productivity.

The sum of the two input elasticities (capital and labor) amounts to 1.0481 in the regime without IT outsourcing and to 0.9845 in the regime with IT outsourcing. In the first case, the null hypothesis of constant returns to scale can be rejected (Wald: $\chi 2=4.30$; $p$-value $=0.0381)$. For IT outsourcing firms, on the other hand, the constant returns to scale hypothesis cannot be rejected (Wald: $\chi 2=0.038 ; p$-value $=0.5724$ ). Also, a test for identical returns to scale for the two regimes can be rejected (Wald: $\chi 2=3.30 ; p$-value $=$ 0.0695). The indicators for the qualification structure of the work force, university degree and vocational education, as well as the existence of a works council and the export share have a significantly positive effect on the labor productivity in both regimes, although the differences between the two regimes are not significant. The dummy variable that indicates if the firms have a foreign subsidiary has a significantly positive contribution only

\footnotetext{
${ }^{33}$ Note that the estimated coefficients for the labor input correspond to $(\gamma-1)$. Adding one to the estimated coefficient yields the partial output elasticity of labor.

${ }^{34}$ Note that the coefficient is equal to labor efficiency times labor elasticity.

35 The partial output elasticity for the share of computer workers, which is equal to the difference in relative labor efficiency between computer and non-computer workers, in the non-IT outsourcing regime is $0.5199[=0.4867 /(-0.0639+1)]$ and $1.0971[=0.9686 /(-0.1171+1)]$ for the IT outsourcing regime.
} 
for non-IT outsourcing firms. In both regimes the dummy variables describing the amount of innovative IT systems employed by the firms are only significant for nine and ten applications (the base group consists of firms employing zero or one IT application) with no significant differences between the outsourcing and non-outsourcing regime. Firm age dummies are insignificant in both regimes. The dummy variable that indicates whether a firm is located in East Germany has a significant and negative coefficient, which reflects lower labor productivity in East Germany. Interestingly, the difference between the two regimes is highly significant, leading to the result that East German IT outsourcing firms are less productive than their non-outsourcing counterparts. Some, but not all of the industry dummies are significant (the base category is metal and machine construction). In this setting the coefficients of the sector dummies have no specific economic meaning. They rather control for different measurements of labor productivity and other factors across industries. Additionally, a Wald test for identity of the factor inputs (capital and labor) cannot be rejected, whereas the identity of the other factors included in the productivity equations ${ }^{36}$ as well as the identity of the entire set of variables can be rejected.

An important result refers to the constant terms in both productivity regimes, which in a production function framework reflect multi-factor productivity. In both regimes the constant term is significant, but it is significantly larger in the IT outsourcing regime. This implies that firms being involved in IT outsourcing produce in general more efficiently than firms that do not outsource.

In order to visualize the joint effects of the differences in the partial output elasticities for IT outsourcers and non-IT outsourcers and the firm heterogeneity parameters, Kernel density estimates of the conditional log labor productivity distributions in the two regimes are compared. The results thereof are displayed in Figures 6 and 7. These figures show the joint productivity effects of IT outsourcing arising from changes in the output elasticities of the input factors and from the changes in the observable firm heterogeneity parameters. In addition, the selectivity effect resulting from the firms' decision whether or not to outsource IT services is taken into account. The idea behind the figures is to consider the same firms - those with IT outsourcing (Figure 6) and those without IT outsourcing

\footnotetext{
${ }^{36}$ Specifically those are East Germany, university degree and vocational education, works council, export share, foreign subsidiary and firm age.
} 
(Figure 7)- under the two different outsourcing regimes. In order to control for the fact that firms with IT outsourcing might be systematically different from those without IT outsourcing and thus might differ in their decision to engage in IT outsourcing, the productivity distributions are estimated conditional on the choice of firms concerning IT outsourcing. ${ }^{37}$

The solid curve in Figure 6 represents Kernel density estimates for log labor productivity related to the parameter vector with IT outsourcing and firms which actually conduct IT outsourcing, while the dashed curve corresponds to the parameter vector without IT outsourcing and firms which engaged in IT outsourcing. ${ }^{38}$ In both figures, the log labor productivity distribution with IT outsourcing is located to the right of the regime without IT outsourcing. However, the productivity differentials in the log labor productivity between the two regimes are larger for firms which are actually involved in IT outsourcing. This means that the firms with IT outsourcing are clearly better off compared to the hypothetical case without IT outsourcing. On the other hand, those firms without IT outsourcing would not have gained that much if they had actually outsourced their IT (although the differences is still significant, see below for more details). Thus, it seems that on average the firms take "the right decision" with respect to IT outsourcing since IT outsourcing is more profitable for firms that actually decided to do it.

To underpin the just presented graphical findings for log labor productivity, t-tests are conducted that indicate a significant shift in the mean log labor productivity between the regimes with and without IT outsourcing. Table 11 displays the corresponding test results. The mean log labor productivity of firms that are involved in IT outsourcing turns out to be significantly higher compared to the hypothetical mean log labor productivity for the case that these firms did not source out their IT. Firms that have already outsourced IT have for instance reorganized their workplaces and business processes allowing a more efficient production process such that an abandonment of IT outsourcing would cause a tremendous drop in the firms' productivity. Non-IT outsourcing firms would also be better off if they outsourced their IT services. However, the hypothetical gain

\footnotetext{
${ }^{37}$ Details on the calculations are displayed in Equation (14).

38 The solide curve in Figure 6 is calculated from the fitted values $\boldsymbol{V}_{\boldsymbol{i}} \hat{\boldsymbol{\delta}}_{\boldsymbol{o}}$ while the circled curve is calculated from the fitted values $\boldsymbol{V}_{\boldsymbol{i}} \hat{\boldsymbol{\delta}}_{\text {no }}$, where $\boldsymbol{V}_{\boldsymbol{i}}$ includes only those firms with IT outsourcing, plus the selectivity parameter resulting from the choice of the firms whether or not to engage in IT outsourcing, respectively.
} 
in productivity non-IT outsourcing firms would realize is smaller than the hypothetical loss in productivity for firms that currently are involved in IT outsourcing. Interestingly, the unconditional mean difference between the estimated and the hypothetical labor productivity (the first summand in Equation (14)) is nearly the same for firms with and without IT outsourcing, as displayed in Table 12. If non-IT outsourcing firms were supposed to produce according to the production function of firms in the regime with IT outsourcing, thus implicitly assuming that non-IT outsourcing firms made equivalent organizational adjustment or acquired equivalent organizational resources like firms in the regime with IT outsourcing, non-IT outsourcing firms would realize a considerable gain in labor productivity. However, due to the selection into the regime without IT outsourcing (the second summand in Equation (14)) the conditional mean difference in labor productivity is smaller. One possible explanation might be that firms selected into the regime without IT outsourcing do so because they expect that the costs involved with IT outsourcing would not be sufficiently outweighed by productivity gains (see Equation (6)). Therefore, the higher gain in productivity for firms with IT outsourcing is a result of the selection into the regime with IT outsourcing.

\subsection{Firm Growth Results}

To examine the growth rate of the firms' workforce, a 2SLS estimation procedure (in two specifications, see also Section 4) is applied. I choose again the variable Y2K consulting as an instrument variable for IT outsourcing, which is assumed to be correlated with the IT outsourcing decision and on the other side is independent from the employment growth rate. The first stage results of the estimation, which are displayed in Table 13, show a highly significant and positive coefficient for Y2K consulting in both model specifications. This result supports the use of the variable as an instrument for IT outsourcing. Y2K consulting activity is considered to be exogenous to the growth rate of the workforce.

Table 14 shows the second stage estimation results. In the parsimoniously specified model (Specification (I)) first, it can be seen that the coefficient for IT outsourcing is positive but insignificant. To control for the initial size of the firm, $\ln ($ labor $)$ and its squared term are included into the regression. There is a positive effect of the firm size on the growth rate of the workforce which diminishes as indicated by the negative 
coefficient of $\ln (\text { labor })^{2}$. The share of employees with university degree has a positive and significant effect on firm growth. Furthermore, only the automobile industry shows a significant positive deviation from the base category (metal and machine construction industry).

If I add variables for the IT intensity and internationalization of the firms to the regression equation (Specification (II)), the result regarding the effect of IT outsourcing changes. Now, the coefficient is also statistically significant, indicating a positive effect of IT outsourcing on the subsequent employment growth rate of the firm. Firm growth again is increasing with initial firm size $(\ln ($ labor $)$ however with diminishing rates. Whereas the internationalization variables, export share and the existence of a foreign subsidiary, have no effect, a low number of IT applications has a significantly negative impact on the growth rate. This result reflects that in an increasingly computerized world, firms which use less internet or software applications in their production process also have inferior growth prospects. Interestingly, a higher share of computer workers leads also to a higher growth rate of total employment. A possible explanation therefore might be an efficiency gain through computer workplaces which makes it possible for firms to create new jobs further on. Controlling for the share of computer workers in the starting period, the growth rate of this share has no significant effect on employment growth. The firm age too, indicates no significant effect on the subsequent growth of the workforce. As for the last variable reflecting firms' IT intensity, the coefficient of the change in the number of IT specialists employed by the firms is positive and highly significant. This implies that an increase in IT specialist also results in an overall growth of the firm. The highly positive significance of the share of employees with a university degree in Specification (I) might be captured through the change in the number of IT specialist employed in Specification (II), since in this formulation the share of employees with university degree has no effect on firms' employment growth anymore. 39

\footnotetext{
39 The change in standard wages between 1999 and 2003 has no significant effect on the firms' employment growth in the same time span.
} 


\section{Conclusion}

The aim of this paper is to analyze the effects of IT outsourcing on different measures of firm performance. In a fist step, the relationship between IT outsourcing and firms' labor productivity is examined using an endogenous switching regression model which separates firms into two regimes, IT outsourcing and non-IT outsourcing firms. This method allows IT outsourcing to affect the productivity elasticities of the input factors differently in both groups. Moreover, it takes account of potential simultaneity between the decision to source out IT and the firms' labor productivity. In a further step, the medium-term effect of IT outsourcing on firms' employment growth rate is examined, thereby using an instrumental variable approach to account for the possible endogeneity of IT outsourcing on the growth rate of the workforce. For both analyzes, German firm-level data from a comprehensive survey conducted in the years 2000 and 2004 is utilized.

The use of an endogenous switching regression model to account for the simultaneity between IT outsourcing and labor productivity seems to be justified due to the jointly and individually significant correlation parameters between each of the two productivity equations and the selection equation. The estimation results show that firms which are actively outsourcing basic IT services have a significantly higher production efficiency as measured by the constant term compared to firms not involved in IT outsourcing. The second important result of this paper refers to the difference in the contribution of employees working at a computerized workplace to labor productivity in the two regimes. The partial output elasticities are both positive, but significantly larger in the regime with IT outsourcing. This result hints to a positive complementarity between IT outsourcing and the share of employees working at a computerized workplace. Together, both factors affect labor productivity positively.

The instrumental variable approach is applied in order to investigate the impact of IT outsourcing on firms' employment growth. A rather parsimonious specification shows no significant impact on the growth rate, although the coefficient is positive. The second specification, which includes variables to account for the IT intensity and the internationalization of the firms, gives evidence for a positive relationship between IT outsourcing 
and firms' subsequent medium-term growth rate, since the estimated coefficient for the outsourcing of basic IT services is significantly positive.

Summarizing the results, I could find evidence for a positive impact of IT outsourcing on firm performance. Nevertheless, there are a couple of questions which remain unsolved, being a starting point for future research. First of all, the analysis in this paper is only dealing with the outsourcing activities of basic IT services. Further research could concentrate on the outsourcing effects of specialized IT services which might bring efficiency gains to the outsourcing company through a better quality of service offered by the external IT vendor. Second, the aspect of IT offshoring, i.e. outsourcing to a foreign service provider, couldn't be reflected in this paper. Although, as shown in Section 1, IT offshoring gained in importance during the last years, IT outsourcing is still predominantly done locally. 


\section{Appendix}

Figure 1: Outsourcing of IT services in the EU in 2006

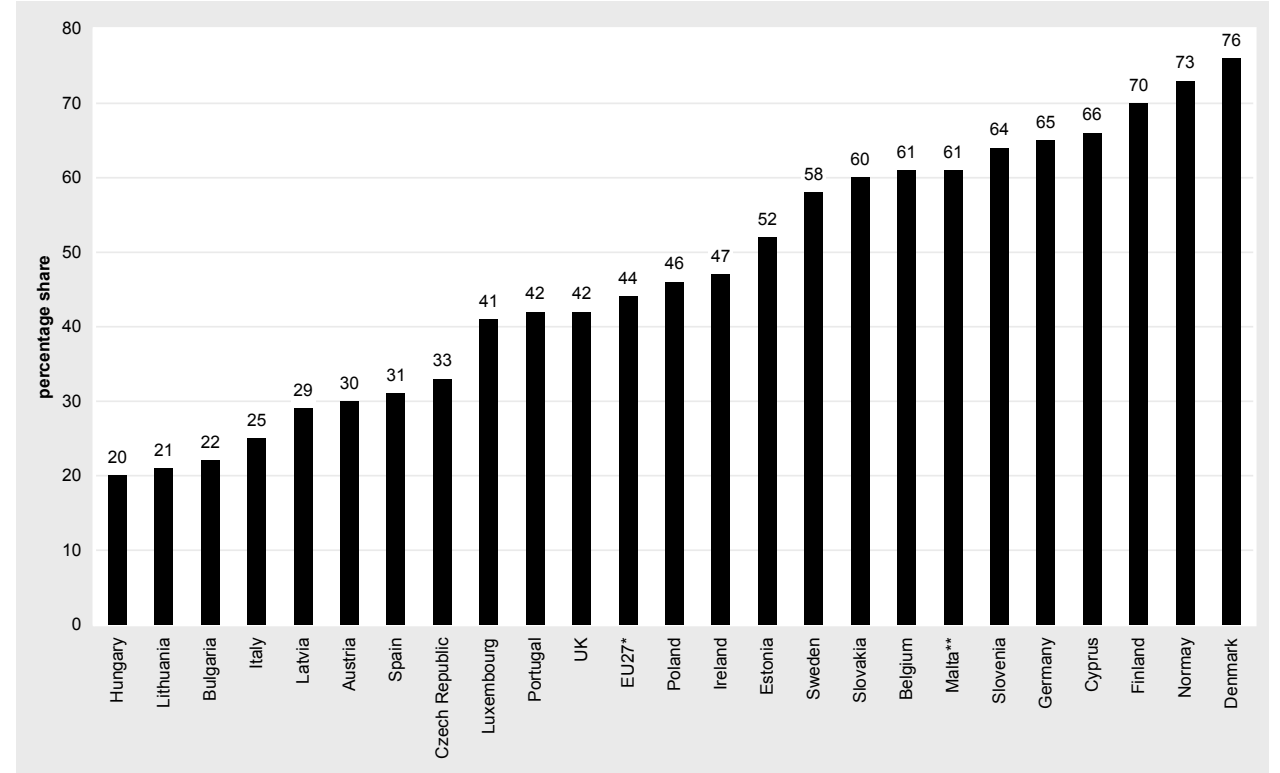

Note: Enterprises where ICT functions requiring ICT/IT specialists were performed (fully or partly) by external suppliers, during 2006. Data from Greece, France, Netherlands and Romania is not available. Result for Malta is provisional.

Source: Eurostat, ICT statistics.

Figure 2: Intermediate IT input share at total intermediate input in Germany (1991-2004)

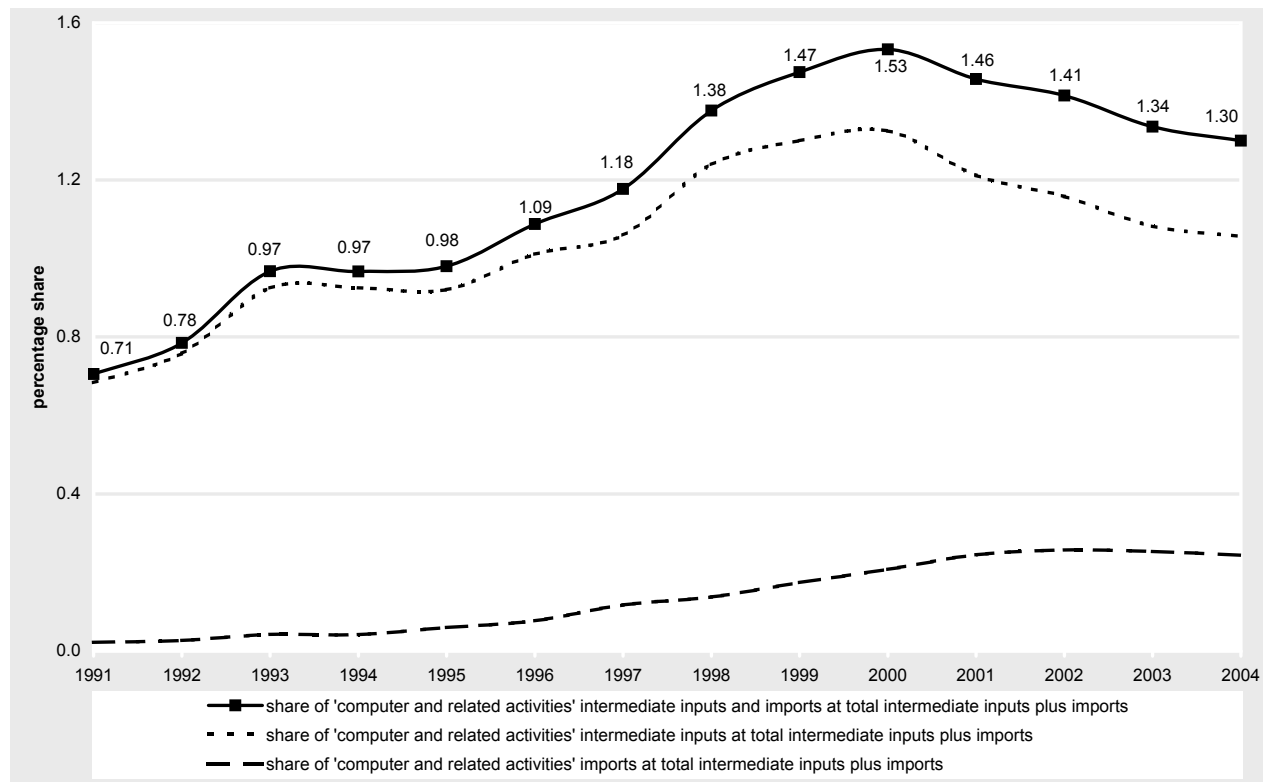

Note: "Computer and related activities" corresponds to NACE 72.

Source: German Statistical Office and own calculations. 
Figure 3: Intermediate IT input share at total intermediate input in the USA (1998-2005)

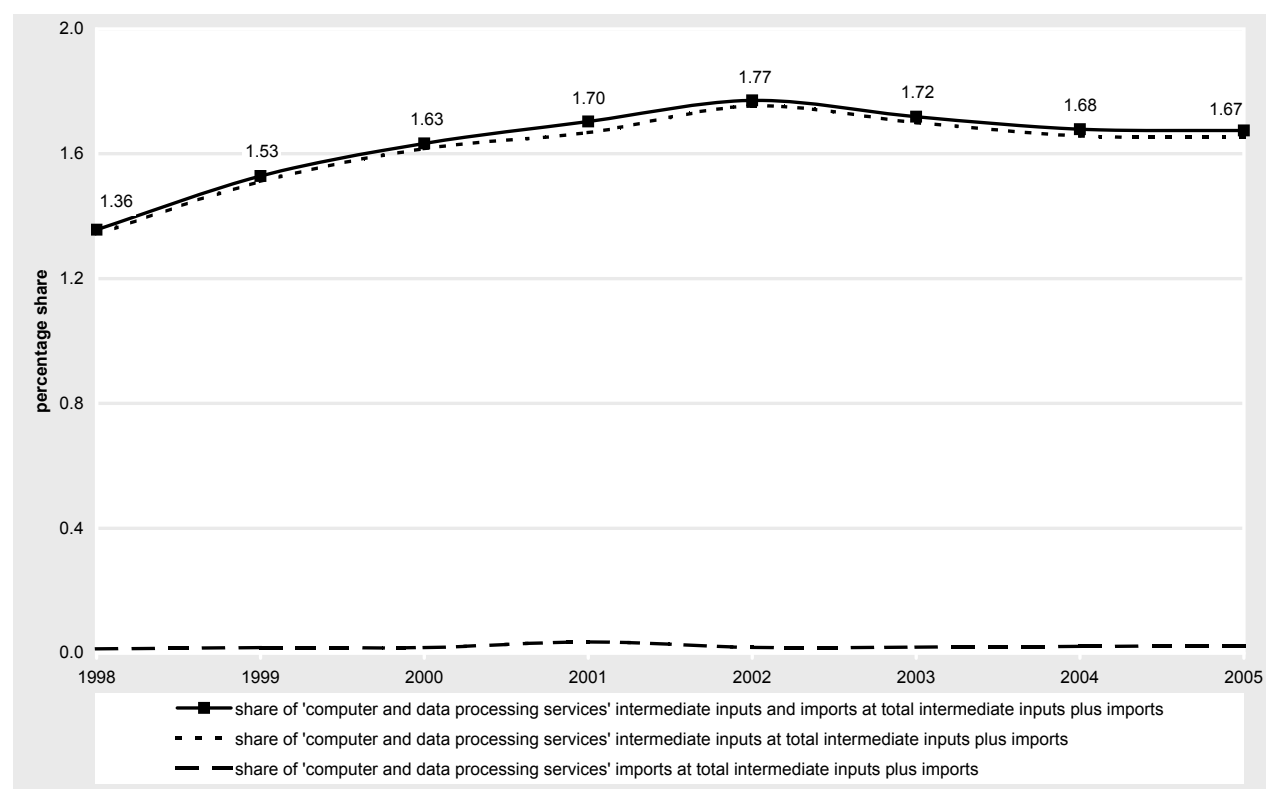

Note: "Computer and data processing services" consist of "Information and data processing services" (NAICS 514) and "Computer systems design and related services" (NAICS 5415).

Source: U.S. Department of Commerce - Bureau of Economic Analysis and own calculations.

Table 1: Comparison of sample and population by industry

\begin{tabular}{|c|c|c|c|c|c|}
\hline \multirow[b]{3}{*}{ Industry } & \multicolumn{3}{|c|}{ Number of firms } & \multicolumn{2}{|c|}{ Sales } \\
\hline & \multicolumn{2}{|c|}{ Sample } & \multirow{2}{*}{$\begin{array}{c}\text { Population }^{1} \\
\%\end{array}$} & \multirow{2}{*}{$\begin{array}{c}\text { Sample } \\
\%\end{array}$} & \multirow{2}{*}{$\begin{array}{c}\text { Population }^{2} \\
\%\end{array}$} \\
\hline & $\#$ & $\%$ & & & \\
\hline consumer goods & 230 & 9.85 & 5.45 & 6.31 & 7.60 \\
\hline chemical industry & 140 & 5.99 & 0.58 & 16.00 & 6.11 \\
\hline other raw materials & 202 & 8.65 & 2.09 & 6.07 & 4.11 \\
\hline metal and machine construction & 289 & 12.37 & 4.71 & 6.25 & 6.57 \\
\hline electrical engineering & 159 & 6.81 & 1.20 & 4.75 & 3.76 \\
\hline precision instruments & 218 & 9.33 & 0.76 & 5.21 & 0.88 \\
\hline automobile & 161 & 6.89 & 0.39 & 10.96 & 7.89 \\
\hline wholesale trade & 127 & 5.44 & 9.52 & 5.92 & 14.56 \\
\hline retail trade & 171 & 7.32 & 35.71 & 12.91 & 14.33 \\
\hline transportation and postal serv. & 173 & 7.41 & 9.47 & 5.08 & 4.40 \\
\hline banks and insurances & 113 & 4.84 & 1.06 & 17.22 & 20.88 \\
\hline technical services & 194 & 8.30 & 5.01 & 1.22 & 0.81 \\
\hline other business-related services & 159 & 6.81 & 21.37 & 2.11 & 4.93 \\
\hline Total & 2,336 & 100.00 & 100.00 & 100.00 & 100.00 \\
\hline
\end{tabular}

Note: ${ }^{1}$ Share of firms with five and more employees in the respective industry in Germany $2004 .{ }^{2}$ Share of sales of firms with five and more employees in the respective industry in Germany 2004.

Source: German Statistical Office, ZEW and own calculations. 
Table 2: Comparison of sample and population by size class

\begin{tabular}{|c|c|c|c|c|c|}
\hline \multirow{3}{*}{$\begin{array}{l}\text { Size class } \\
\text { (\# of employees) }\end{array}$} & \multicolumn{3}{|c|}{ Number of firms } & \multicolumn{2}{|c|}{ Sales } \\
\hline & \multicolumn{2}{|c|}{ Sample } & \multirow{2}{*}{$\begin{array}{c}\text { Population }^{1} \\
\%\end{array}$} & \multirow{2}{*}{$\begin{array}{c}\text { Sample } \\
\%\end{array}$} & \multirow{2}{*}{$\begin{array}{c}\text { Population } \\
\%\end{array}$} \\
\hline & $\#$ & $\%$ & & & \\
\hline $5-9$ & 306 & 13.10 & 52.91 & 0.22 & 5.78 \\
\hline $10-19$ & 332 & 14.21 & 20.24 & 0.43 & 4.23 \\
\hline $20-49$ & 479 & 20.51 & 15.09 & 1.62 & 6.84 \\
\hline $50-99$ & 396 & 16.95 & 5.75 & 3.06 & 6.61 \\
\hline $100-249$ & 366 & 15.67 & 3.56 & 7.41 & 9.72 \\
\hline $250-499$ & 197 & 8.43 & 1.32 & 9.34 & 10.00 \\
\hline 500 and more & 260 & 11.13 & 1.12 & 77.91 & 56.82 \\
\hline Total & 2,336 & 100.00 & 100.00 & 100.00 & 100.00 \\
\hline
\end{tabular}

Note: ${ }^{1}$ Share of firms (adjusted for the regarded industries) in the respective size class in Germany 2004. ${ }^{2}$ Share of sales of firms (adjusted for the regarded industries) in the respective size class in Germany 2004.

Source: German Statistical Office, ZEW and own calculations.

Table 3: Number and share of firms involved in IT outsourcing by industry

\begin{tabular}{|c|c|c|c|c|c|c|}
\hline \multirow[b]{2}{*}{ Industry } & \multicolumn{2}{|c|}{$\begin{array}{c}\text { IT outsourcing } \\
2004\end{array}$} & \multicolumn{2}{|c|}{$\begin{array}{l}\text { IT outsourcing } \\
2000(\text { Spec. (I)) }\end{array}$} & \multicolumn{2}{|c|}{$\begin{array}{l}\text { IT outsourcing } \\
2000(\text { Spec. (II)) }\end{array}$} \\
\hline & $\#$ & $\%$ & $\#$ & $\%$ & $\#$ & $\%$ \\
\hline consumer goods & 106 & 46.09 & 36 & 52.17 & 27 & 56.25 \\
\hline chemical industry & 56 & 40.00 & 34 & 53.13 & 25 & 52.08 \\
\hline other raw materials & 82 & 40.59 & 49 & 56.32 & 36 & 52.94 \\
\hline metal and machine const. & 114 & 39.45 & 44 & 47.31 & 34 & 54.84 \\
\hline electrical engineering & 37 & 23.27 & 21 & 28.00 & 13 & 25.00 \\
\hline precision instruments & 83 & 38.07 & 36 & 45.57 & 27 & 48.21 \\
\hline automobile & 63 & 39.13 & 30 & 39.47 & 22 & 43.14 \\
\hline wholesale trade & 59 & 46.46 & 29 & 63.04 & 21 & 65.63 \\
\hline retail trade & 72 & 42.11 & 30 & 58.82 & 16 & 50.00 \\
\hline transport and postal serv. & 72 & 41.62 & 31 & 46.27 & 25 & 47.17 \\
\hline banks and insurances & 45 & 39.82 & 31 & 50.82 & 25 & 51.02 \\
\hline technical services & 56 & 28.87 & 21 & 29.17 & 11 & 22.45 \\
\hline other business-related serv. & 74 & 46.54 & 27 & 38.57 & 22 & 37.29 \\
\hline Total & 919 & 39.34 & 419 & 46.04 & 304 & 46.13 \\
\hline
\end{tabular}

Note: Number and share of firms involved in basic IT outsourcing in 2004 and 2000 (for each specification). Source: ZEW ICT-survey 2000, 2004 and own calculations. 
Figure 4: IT outsourcing 2004 vs firm size

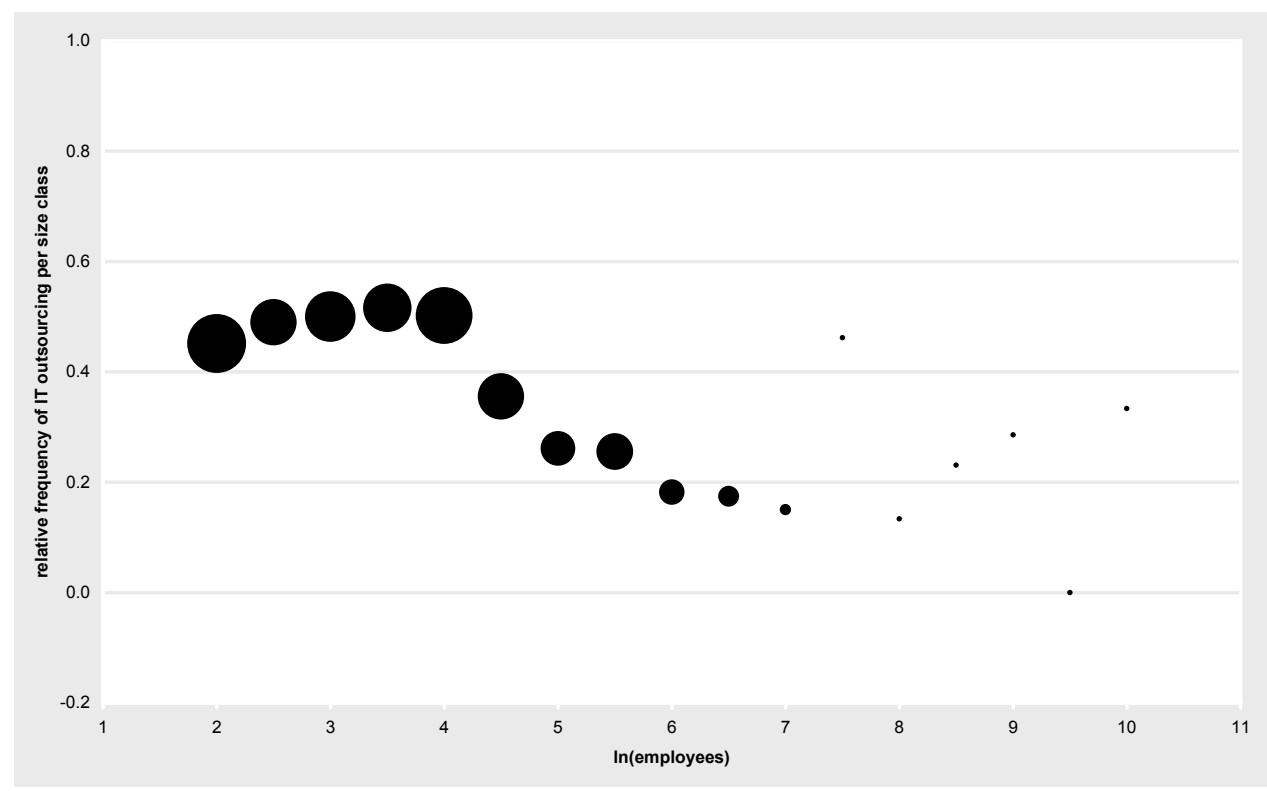

Note: $\ln ($ employees $)$ grouped into equi-spaced intervals versus the relative frequencies of IT outsourcing. The size of the dots indicates the number of firms in the considered interval.

Source: ZEW ICT-survey 2004 and own calculations.

Figure 5: IT outsourcing 2000 vs firm size

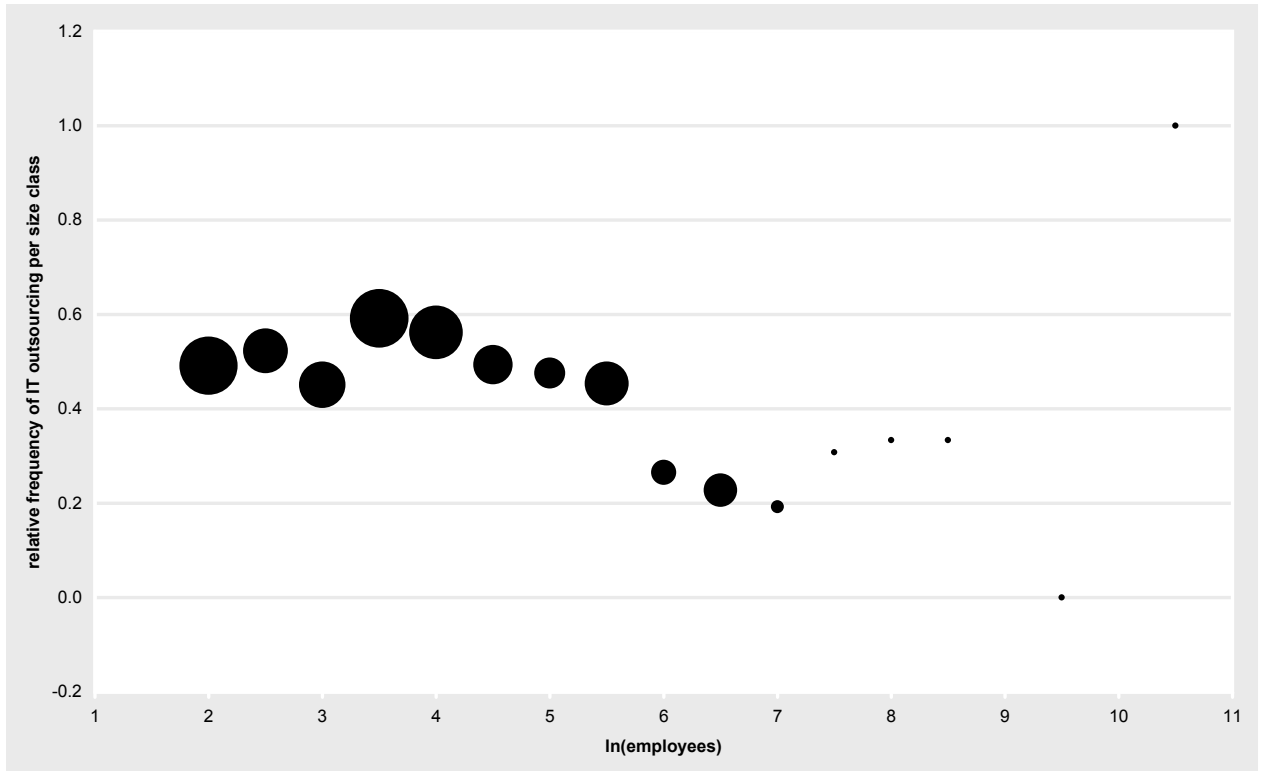

Note: $\ln ($ employees $)$ grouped into equi-spaced intervals versus the relative frequencies of IT outsourcing. The size of the dots indicates the number of firms in the considered interval. The sample for Specification (I) in the employment growth estimation is the underlying data.

Source: ZEW ICT-survey 2000 and own calculations. 
Table 4: Summary statistics for productivity analysis

\begin{tabular}{|c|c|c|c|c|c|c|}
\hline \multirow[b]{2}{*}{ Variable } & \multirow[b]{2}{*}{ Mean } & \multirow{2}{*}{$\begin{array}{l}\text { Std. } \\
\text { Dev. }\end{array}$} & \multicolumn{3}{|c|}{ Quantiles } & \multirow{2}{*}{$\begin{array}{l}\text { Dummy } \\
\text { variable }\end{array}$} \\
\hline & & & $10 \%$ & $50 \%$ & $90 \%$ & \\
\hline output $^{\natural}$ & $29,306.2$ & $190,553.5$ & 349.8 & $3,155.5$ & $46,508.6$ & \\
\hline labor productivity ${ }^{\S}$ & 113.3 & 232.1 & 24.6 & 58.0 & 208.0 & \\
\hline capital $^{\dagger}$ & 2435.1 & $14,996.1$ & 15.0 & 200.0 & $5,000.0$ & \\
\hline labor $\diamond$ & 244.7 & 939.6 & 7.5 & 50.0 & 503.0 & \\
\hline $\ln$ (output) & 8.204 & 1.872 & 5.9 & 8.1 & 10.7 & \\
\hline $\ln$ (labor productivity) & 4.183 & 0.894 & 3.2 & 4.1 & 5.3 & \\
\hline $\ln ($ capital $)$ & 5.508 & 2.163 & 2.7 & 5.3 & 8.5 & \\
\hline $\ln$ (labor) & 4.021 & 1.582 & 2.0 & 3.9 & 6.2 & \\
\hline share of computer workers & 0.422 & 0.308 & 0.1 & 0.3 & 1.0 & \\
\hline IT outsourcing 2004 & 0.393 & 0.489 & 0.0 & 0.0 & 1.0 & yes \\
\hline Y2K consulting & 0.536 & 0.499 & 0.0 & 1.0 & 1.0 & yes \\
\hline East Germany & 0.226 & 0.419 & 0.0 & 0.0 & 1.0 & yes \\
\hline university degree & 0.187 & 0.228 & 0.0 & 0.1 & 0.5 & \\
\hline vocational education & 0.593 & 0.250 & 0.2 & 0.6 & 0.9 & \\
\hline works council & 0.396 & 0.489 & 0.0 & 0.0 & 1.0 & yes \\
\hline foreign subsidiary & 0.137 & 0.344 & 0.0 & 0.0 & 1.0 & \\
\hline export share & 0.168 & 0.246 & 0.0 & 0.0 & 0.6 & yes \\
\hline firm age (in years) & 19.345 & 19.821 & 5 & 14 & 36 & \\
\hline IT applications & 5.400 & 2.458 & 2 & 5 & 9 & \\
\hline consumer goods & 0.098 & 0.298 & - & - & - & yes \\
\hline chemical industry & 0.060 & 0.237 & - & - & - & yes \\
\hline other raw materials & 0.086 & 0.281 & - & - & - & yes \\
\hline metal and machine const. & 0.124 & 0.329 & - & - & - & yes \\
\hline electrical engineering & 0.068 & 0.252 & - & - & - & yes \\
\hline precision instruments & 0.093 & 0.291 & - & - & - & yes \\
\hline automobile & 0.069 & 0.253 & - & - & - & yes \\
\hline wholesale trade & 0.054 & 0.227 & - & - & - & yes \\
\hline retail trade & 0.073 & 0.261 & - & - & - & yes \\
\hline transport and postal serv. & 0.074 & 0.262 & - & - & - & yes \\
\hline banks and insurances & 0.048 & 0.215 & - & - & - & yes \\
\hline technical services & 0.083 & 0.276 & - & - & - & yes \\
\hline other business-related serv. & 0.068 & 0.252 & - & - & - & yes \\
\hline Number of observations & & & & & & \\
\hline
\end{tabular}

Note: ${ }^{\natural}$ Output is measured as balance-sheet total for banks and insurance premium total for insurance companies. All output is in $€ 1,000$. ${ }^{\S}$ Value added per employee (in 2003) in $€ 1,000 .{ }^{\dagger}$ Capital is proxied by gross investment in $€ 1,000$. $\diamond$ Labor is measured in full time equivalent units.

Source: ZEW ICT-survey 2004 and own calculations. 
Table 5: Summary statistics for productivity analysis broken down into non-IT outsourcing firms and IT outsourcing firms

\begin{tabular}{|c|c|c|c|c|}
\hline \multirow[b]{2}{*}{ Variable } & \multicolumn{2}{|c|}{ non-IT outsourcer } & \multicolumn{2}{|c|}{ IT outsourcer } \\
\hline & Mean & Std. Dev. & Mean & Std. Dev. \\
\hline output ${ }^{\natural}$ & $36,428.7$ & $23,1357.6$ & $18,324.0$ & $97,960.1$ \\
\hline labor productivity ${ }^{\S}$ & 110.0 & 219.3 & 118.4 & 250.6 \\
\hline capital $^{\dagger}$ & $2,596.2$ & $8,999.3$ & $2,186.6$ & $21,141.9$ \\
\hline labor $\diamond$ & 297.1 & $1,006.2$ & 163.8 & 820.3 \\
\hline $\ln ($ output) & 8.460 & 1.949 & 7.811 & 1.673 \\
\hline $\ln$ (labor productivity) & 4.180 & 0.860 & 4.188 & 0.943 \\
\hline $\ln ($ capital $)$ & 5.829 & 2.180 & 5.012 & 2.041 \\
\hline $\ln ($ labor $)$ & 4.280 & 1.639 & 3.623 & 1.399 \\
\hline share of computer workers & 0.452 & 0.310 & 0.374 & 0.300 \\
\hline Y2K consulting & 0.466 & 0.499 & 0.643 & 0.479 \\
\hline East Germany & 0.202 & 0.402 & 0.264 & 0.441 \\
\hline university degree & 0.212 & 0.241 & 0.148 & 0.199 \\
\hline vocational education & 0.569 & 0.249 & 0.629 & 0.247 \\
\hline works council & 0.457 & 0.498 & 0.303 & 0.460 \\
\hline foreign subsidiary & 0.178 & 0.383 & 0.075 & 0.264 \\
\hline export share & 0.191 & 0.259 & 0.131 & 0.220 \\
\hline firm age (in years) & 19.849 & 20.172 & 18.569 & 19.251 \\
\hline IT applications & 5.665 & 2.437 & 4.990 & 2.434 \\
\hline consumer goods & 0.088 & 0.283 & 0.115 & 0.320 \\
\hline chemical industry & 0.059 & 0.236 & 0.061 & 0.239 \\
\hline other raw materials & 0.085 & 0.279 & 0.089 & 0.285 \\
\hline metal and machine const. & 0.124 & 0.329 & 0.124 & 0.330 \\
\hline electrical engineering & 0.086 & 0.281 & 0.040 & 0.197 \\
\hline precision instruments & 0.095 & 0.294 & 0.090 & 0.287 \\
\hline automobile & 0.069 & 0.254 & 0.069 & 0.253 \\
\hline wholesale trade & 0.048 & 0.214 & 0.064 & 0.245 \\
\hline retail trade & 0.070 & 0.255 & 0.078 & 0.269 \\
\hline transport and postal serv. & 0.071 & 0.257 & 0.078 & 0.269 \\
\hline banks and insurances & 0.048 & 0.214 & 0.049 & 0.216 \\
\hline technical services & 0.097 & 0.297 & 0.061 & 0.239 \\
\hline other business-related serv. & 0.060 & 0.238 & 0.081 & 0.272 \\
\hline Number of observations & \multicolumn{2}{|c|}{1,417} & \multicolumn{2}{|c|}{919} \\
\hline
\end{tabular}

Note: ${ }^{\natural}$ Output is measured as balance-sheet total for banks and insurance premium total for insurance companies. All output is in $€ 1,000$. ${ }^{\S}$ Value added per employee (in 2003) in $€ 1,000$. ${ }^{\dagger}$ Capital is proxied by gross investment in $€ 1,000$. $\diamond$ Labor is measured in full time equivalent units.

Source: ZEW ICT-survey 2004 and own calculations. 
Table 6: Summary statistics for the employment growth analysis

\begin{tabular}{|c|c|c|c|c|c|}
\hline \multirow[b]{2}{*}{ Variable } & \multicolumn{2}{|c|}{ Spec. (I) } & \multicolumn{2}{|c|}{ Spec. (II) } & \multirow{2}{*}{$\begin{array}{l}\text { Dummy } \\
\text { variable }\end{array}$} \\
\hline & Mean & Std. Dev. & Mean & Std Dev. & \\
\hline employment growth (99-03) & -0.086 & 0.797 & -0.064 & 0.772 & \\
\hline labor 1999 & 337.223 & $1,683.5$ & 323.440 & 1.872 .010 & \\
\hline university degree & 20.538 & 22.709 & 20.627 & 23.116 & \\
\hline vocational education & 58.525 & 25.197 & 58.551 & 25.688 & \\
\hline East Germany & 0.224 & 0.417 & 0.241 & 0.428 & yes \\
\hline IT outsourcing & 0.460 & 0.499 & 0.461 & 0.499 & yes \\
\hline Y2K consulting & 0.536 & 0.499 & 0.540 & 0.499 & yes \\
\hline firm age (in years) & - & - & 19.083 & 23.253 & \\
\hline IT applications & - & - & 9.821 & 3.314 & \\
\hline$\triangle$ standard wages $(99-03)$ & - & - & 10.231 & 0.901 & \\
\hline computer workers & - & - & 45.965 & 31.090 & \\
\hline$\triangle$ computer workers $(00-04)$ & - & - & 50.849 & 259.092 & \\
\hline$\triangle$ IT specialists $(00-04)$ & - & - & -0.056 & 0.877 & \\
\hline foreign subsidiary & - & - & 0.185 & 0.389 & yes \\
\hline export share 1999 & - & - & 15.055 & 22.811 & \\
\hline consumer goods & 0.076 & 0.265 & 0.073 & 0.260 & yes \\
\hline chemical industry & 0.070 & 0.256 & 0.073 & 0.260 & yes \\
\hline other raw materials & 0.096 & 0.294 & 0.103 & 0.304 & yes \\
\hline metal and machine const. & 0.102 & 0.303 & 0.094 & 0.292 & yes \\
\hline electrical engineering & 0.082 & 0.275 & 0.079 & 0.270 & yes \\
\hline precision instruments & 0.087 & 0.282 & 0.085 & 0.279 & yes \\
\hline automobile & 0.084 & 0.277 & 0.077 & 0.267 & yes \\
\hline wholesale trade & 0.051 & 0.219 & 0.049 & 0.215 & yes \\
\hline retail trade & 0.056 & 0.230 & 0.049 & 0.215 & yes \\
\hline transport and postal serv. & 0.074 & 0.261 & 0.080 & 0.272 & yes \\
\hline banks and insurances & 0.067 & 0.250 & 0.074 & 0.263 & yes \\
\hline technical services & 0.079 & 0.270 & 0.074 & 0.263 & yes \\
\hline other business-related serv. & 0.077 & 0.267 & 0.090 & 0.286 & yes \\
\hline Number of observations & & 910 & & & \\
\hline
\end{tabular}

Note: The variables refer to the year 2000 if not otherwise indicated.

Source: ZEW ICT-survey 2000, 2004 and own calculations. 
Table 7: Productivity estimation results - regime equations

\begin{tabular}{|c|c|c|c|c|}
\hline \multirow[t]{2}{*}{$\begin{array}{l}\text { Estimation } \\
\text { Results for ... }\end{array}$} & \multicolumn{2}{|c|}{$\begin{array}{l}\ldots \text { regime } \mathrm{w} / \mathrm{o} \\
\text { IT } \text { outsourcing }\end{array}$} & \multicolumn{2}{|c|}{$\begin{array}{l}\ldots \text { regime with } \\
\text { IT outsourcing }\end{array}$} \\
\hline & Coeff. & Std. Err. & Coeff. & Std. Err. \\
\hline $\ln$ (capital) & $0.1120^{* * *}$ & 0.0202 & $0.1016^{* * *}$ & 0.0201 \\
\hline $\ln ($ labor) & $-0.0639^{* *}$ & 0.0303 & $-0.1171^{* * *}$ & 0.0337 \\
\hline share of computer workers & $0.4867^{* * *}$ & 0.1053 & $0.9686^{* * *}$ & 0.1331 \\
\hline East Germany & $-0.2806^{* * *}$ & 0.0559 & $-0.4078^{* * *}$ & 0.0605 \\
\hline university degree & $0.0051^{* * *}$ & 0.0017 & $0.0052^{* *}$ & 0.0023 \\
\hline vocational education & $0.0022^{* *}$ & 0.0011 & $0.0031^{* *}$ & 0.0012 \\
\hline works council & $0.1459^{* *}$ & 0.0573 & $0.1247^{*}$ & 0.0685 \\
\hline export share & $0.0027^{* * *}$ & 0.0009 & $0.0044^{* * *}$ & 0.0012 \\
\hline foreign subsidiary & $0.1753^{* * *}$ & 0.0650 & 0.1141 & 0.1118 \\
\hline firm age $(\leq 3$ years $)$ & -0.1065 & 0.0965 & -0.0935 & 0.1167 \\
\hline firm age $(3<$ years $\leq 7)$ & -0.0144 & 0.0568 & -0.0190 & 0.0693 \\
\hline \# IT applications: 2 & 0.0350 & 0.1188 & 0.1158 & 0.1135 \\
\hline \# IT applications: 3 & 0.0493 & 0.1170 & 0.1182 & 0.1077 \\
\hline \# IT applications: 4 & 0.0314 & 0.1036 & 0.0859 & 0.1011 \\
\hline \# IT applications: 5 & 0.1040 & 0.1072 & 0.0652 & 0.0954 \\
\hline \# IT applications: 6 & 0.1709 & 0.1071 & 0.1089 & 0.1092 \\
\hline \# IT applications: 7 & 0.1290 & 0.1045 & 0.1282 & 0.1206 \\
\hline \# IT applications: 8 & 0.1481 & 0.1083 & 0.0012 & 0.1145 \\
\hline \# IT applications: 9 & $0.2647^{* *}$ & 0.1215 & $0.2969^{* *}$ & 0.1361 \\
\hline \# IT applications: 10 & $0.2964^{*}$ & 0.1764 & $0.4945^{* * *}$ & 0.1886 \\
\hline consumer goods & -0.0658 & 0.0766 & $-0.1771^{* *}$ & 0.0811 \\
\hline chemical industry & 0.1110 & 0.0978 & $0.2356^{* *}$ & 0.1065 \\
\hline other raw materials & -0.0171 & 0.0749 & 0.1019 & 0.0941 \\
\hline electrical engineering & -0.0778 & 0.0753 & $-0.2199^{*}$ & 0.1140 \\
\hline precision instruments & 0.0566 & 0.0771 & 0.0544 & 0.0895 \\
\hline automobile & $-0.1972^{* *}$ & 0.0923 & $-0.1663^{*}$ & 0.0998 \\
\hline wholesale trade & $1.2226^{* * *}$ & 0.1321 & $1.1700^{* * *}$ & 0.1233 \\
\hline retail trade & $0.8440^{* * *}$ & 0.0977 & $0.9903^{* * *}$ & 0.1132 \\
\hline transport and postal serv. & $0.2471^{* *}$ & 0.0964 & $0.1833^{* *}$ & 0.0928 \\
\hline banks and insurances & $0.7767^{* * *}$ & 0.1834 & 0.2947 & 0.2091 \\
\hline technical services & -0.0381 & 0.1062 & $-0.4083^{* * *}$ & 0.1217 \\
\hline other business-related serv. & $0.2112^{*}$ & 0.1181 & $0.2889^{* *}$ & 0.1281 \\
\hline Constant & $2.6522^{* * *}$ & 0.1932 & $3.3748^{* * *}$ & 0.1555 \\
\hline$\sigma_{n o}^{2}$ & $0.8155^{* * *}$ & 0.0509 & - & - \\
\hline$\sigma_{o}^{2}$ & - & - & $0.7372^{* * *}$ & 0.0278 \\
\hline$\rho_{n o, \epsilon}$ & $-0.6847^{* * *}$ & 0.1139 & - & - \\
\hline$\rho_{o, \epsilon}$ & - & - & $-0.2514^{* * *}$ & 0.0910 \\
\hline Number of observations & \multicolumn{2}{|c|}{1,417} & \multicolumn{2}{|c|}{919} \\
\hline
\end{tabular}

Note: $* * *$ and ${ }^{* * *}$ indicate significance at the $10 \%, 5 \%$ and $1 \%$ level respectively. Robust standard errors are shown in the Std. Err. columns.

Source: ZEW ICT-survey 2004 and own calculations. 
Table 8: Productivity estimation results - selection equation

\begin{tabular}{|c|c|c|}
\hline & Coeff. & Std. Err. \\
\hline $\ln ($ capital) & -0.0168 & 0.0233 \\
\hline $\ln ($ labor $)$ & $-0.1419^{* * *}$ & 0.0373 \\
\hline share of computer workers & $-0.3143^{* * *}$ & 0.1206 \\
\hline East Germany & $0.1389^{* *}$ & 0.0676 \\
\hline university degree & $-0.0054^{* * *}$ & 0.0020 \\
\hline vocational education & 0.0006 & 0.0014 \\
\hline works council & -0.0787 & 0.0758 \\
\hline export share & -0.0012 & 0.0014 \\
\hline foreign subsidiary & $-0.1626^{*}$ & 0.0988 \\
\hline firm age $(\leq 3$ years $)$ & -0.0548 & 0.1214 \\
\hline firm age $(3<$ years $\leq 7)$ & 0.0543 & 0.0740 \\
\hline \# IT applications: 2 & 0.0733 & 0.1463 \\
\hline \# IT applications: 3 & 0.1641 & 0.1389 \\
\hline \# IT applications: 4 & 0.1748 & 0.1311 \\
\hline \# IT applications: 5 & 0.1058 & 0.1305 \\
\hline \# IT applications: 6 & -0.0228 & 0.1348 \\
\hline \# IT applications: 7 & 0.0299 & 0.1368 \\
\hline \# IT applications: 8 & 0.0589 & 0.1419 \\
\hline \# IT applications: 9 & -0.0786 & 0.1609 \\
\hline \# IT applications: 10 & 0.0106 & 0.2127 \\
\hline Y2K consulting & $0.5173^{* * *}$ & 0.0734 \\
\hline consumer goods & 0.0737 & 0.1152 \\
\hline chemical industry & -0.0206 & 0.1340 \\
\hline other raw materials & -0.0559 & 0.1167 \\
\hline electrical engineering & $-0.3361^{* * *}$ & 0.1304 \\
\hline precision instruments & -0.0743 & 0.1153 \\
\hline automobile & -0.0230 & 0.1307 \\
\hline wholesale trade & -0.0387 & 0.1479 \\
\hline retail trade & $-0.2680^{* *}$ & 0.1293 \\
\hline transport and postal serv. & -0.1188 & 0.1268 \\
\hline banks and insurances & -0.1477 & 0.1897 \\
\hline technical services & -0.1551 & 0.1413 \\
\hline other business-related serv. & 0.1062 & 0.1383 \\
\hline Constant & $0.3316^{*}$ & 0.1879 \\
\hline Number of observations & \multicolumn{2}{|c|}{2336} \\
\hline
\end{tabular}

Note: $* * *$ and $* * *$ indicate significance at the $10 \%, 5 \%$ and $1 \%$ level respectively. Robust standard errors are shown in the Std. Err. column.

Source: ZEW ICT-survey 2004 and own calculations. 
Table 9: Productivity estimation results - Wald test for identity of coefficients in the regime equation

\begin{tabular}{|c|c|c|}
\hline & $\chi^{2}$ & $p$-value \\
\hline $\ln$ (capital) & 0.1375 & 0.7108 \\
\hline $\ln ($ labor $)$ & 1.4313 & 0.2315 \\
\hline share of computer workers* & 9.5069 & 0.0020 \\
\hline East Germany & 2.4669 & 0.1163 \\
\hline university degree & 0.0001 & 0.9931 \\
\hline vocational education & 0.2689 & 0.6041 \\
\hline works council & 0.0598 & 0.8068 \\
\hline export share & 1.1925 & 0.2748 \\
\hline foreign subsidiary & 0.2346 & 0.6281 \\
\hline firm age $(\leq 3$ years $)$ & 0.0079 & 0.9292 \\
\hline firm age $(3<$ years $\leq 7)$ & 0.0027 & 0.9585 \\
\hline \# IT applications: 2 & 0.2582 & 0.6114 \\
\hline \# IT applications: 3 & 0.1975 & 0.6567 \\
\hline \# IT applications: 4 & 0.1509 & 0.6976 \\
\hline \# IT applications: 5 & 0.0772 & 0.7811 \\
\hline \# IT applications: 6 & 0.1751 & 0.6757 \\
\hline \# IT applications: 7 & 0.0000 & 0.9960 \\
\hline \# IT applications: 8 & 0.9247 & 0.3363 \\
\hline \# IT applications: 9 & 0.0330 & 0.8558 \\
\hline \# IT applications: 10 & 0.6161 & 0.4325 \\
\hline consumer goods & 1.0506 & 0.3054 \\
\hline chemical industry & 0.7643 & 0.3820 \\
\hline other raw materials & 1.0590 & 0.3034 \\
\hline electrical engineering & 1.1412 & 0.2854 \\
\hline precision instruments & 0.0004 & 0.9841 \\
\hline automobile & 0.0566 & 0.8120 \\
\hline wholesale trade & 0.0879 & 0.7668 \\
\hline retail trade & 0.9930 & 0.3190 \\
\hline transport and postal serv. & 0.2461 & 0.6198 \\
\hline banks and insurances & 3.0939 & 0.0786 \\
\hline technical services & 5.5294 & 0.0187 \\
\hline other business-related serv. & 0.2092 & 0.6474 \\
\hline Constant & 8.9201 & 0.0028 \\
\hline Set of input factors ${ }^{* *}$ & 3.4017 & 0.1825 \\
\hline Set of IT applications & 5.5205 & 0.7868 \\
\hline Set of sector dummies & 15.9648 & 0.1929 \\
\hline Set of other factors ${ }^{* * *}$ & 16.8983 & 0.0503 \\
\hline Entire specification & 89.0374 & 0.0000 \\
\hline
\end{tabular}

Note: ${ }^{*}$ For the share of computer workers input, the partial output elasticities between the two regimes $\left(\gamma_{o}\right.$ and $\left.\gamma_{n o}\right)$ are compared. In this case the $p$-value calculation is based on the delta method, an approximation which is appropriate in large samples. ${ }^{* *}$ Input factors include capital and labor input. ${ }^{* * *}$ Other factors include the variables East Germany, university degree and vocational education, works council, export share, foreign subsidiary and firm age.

Source: ZEW ICT-survey 2004 and own calculations. 
Table 10: Productivity estimation results - Wald test for joint significance of the selection equation coefficients and the entire switching regression estimation

\begin{tabular}{lcc}
\hline Wald test for joint significance of the selection equation coefficients & \\
\hline & $\chi^{2}$ & $\boldsymbol{p}$-value \\
\hline factor inputs & 36.5825 & 0.0000 \\
set of other explanatory variables (w/o identifier) & 30.8143 & 0.0210 \\
sector dummies & 18.1247 & 0.1120 \\
entire productivity equation variables & 189.4256 & 0.0000 \\
entire selection equation & 273.3388 & 0.0000 \\
\hline
\end{tabular}

Wald test for joint significance of the entire switching regression estimation

\begin{tabular}{lcc}
\hline & $\chi^{2}$ & $\boldsymbol{p}$-value \\
\hline entire switching regression & $30,892.9$ & 0.0000 \\
correlation coefficients & 24.0904 & 0.0000 \\
\hline
\end{tabular}

Source: ZEW ICT-survey 2004 and own calculations.

Figure 6: Changes in the conditional labor productivity distribution due to IT outsourcing: What if firms with IT outsourcing had not outsourced their IT?

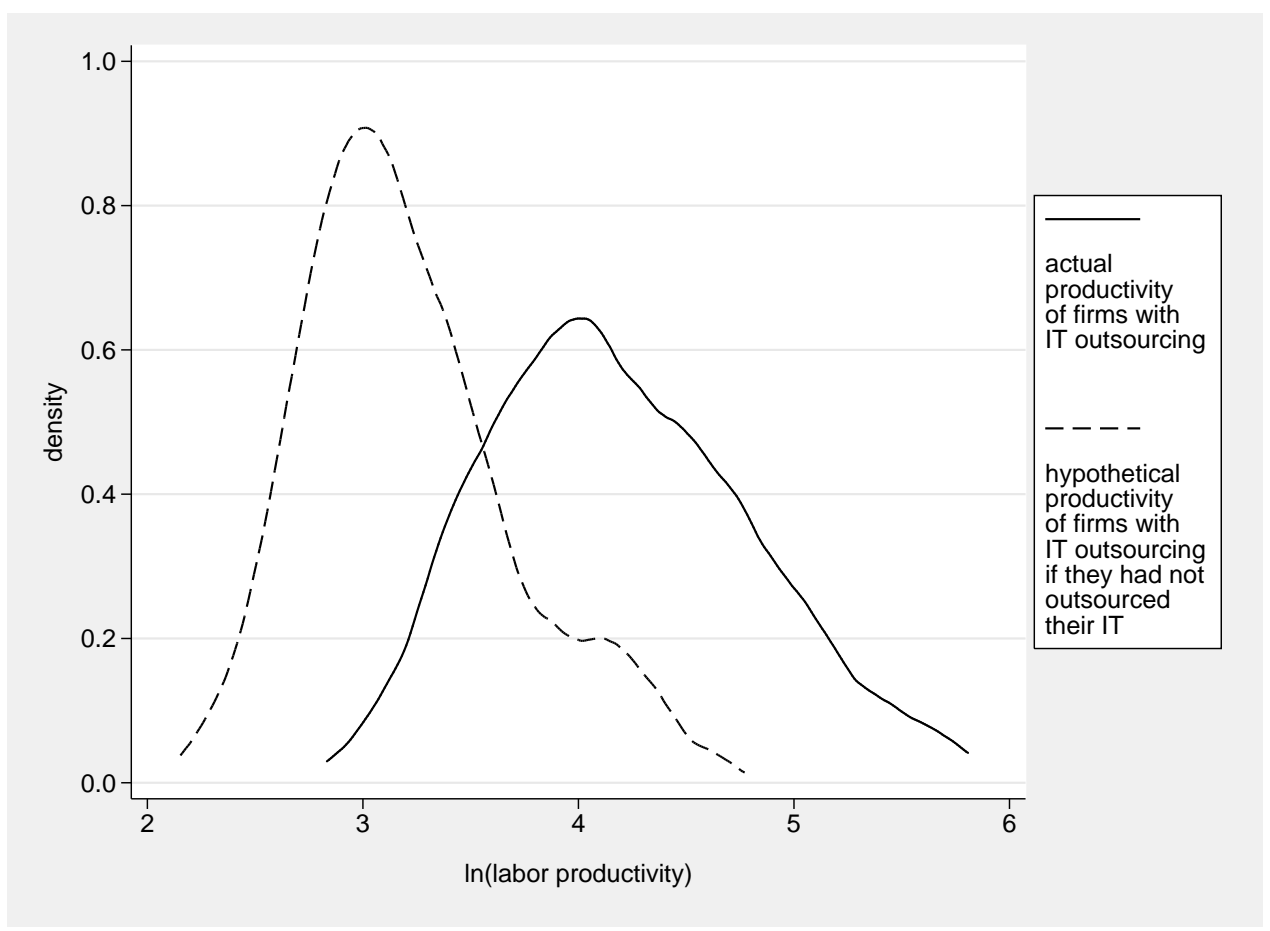

Source: ZEW ICT-survey 2004 and own calculations. 
Figure 7: Changes in the conditional labor productivity distribution due to IT outsourcing: What if firms without IT outsourcing had outsourced their IT?

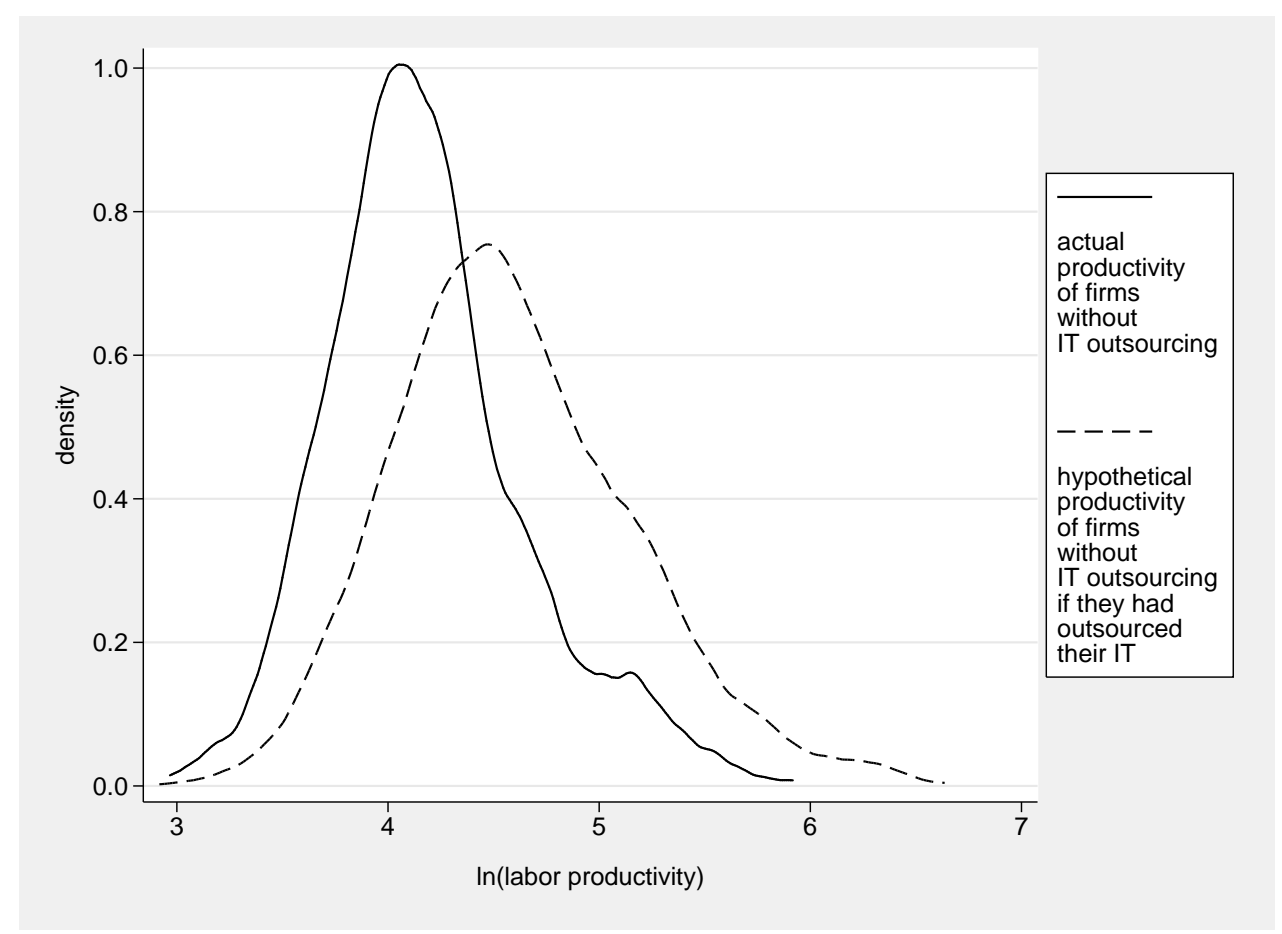

Source: ZEW ICT-survey 2004 and own calculations.

Table 11: Differences in conditional $\ln$ (labor productivity)

\begin{tabular}{lccc}
\hline & $\begin{array}{c}\text { Mean } \\
\text { difference }\end{array}$ & $\begin{array}{c}\text { Std. } \\
\text { Err. }\end{array}$ & $\begin{array}{c}p \text { - } \\
\text { value }\end{array}$ \\
\hline IT outsourcing firms & $0.9797^{\circledast}$ & 0.0079 & 0.0000 \\
non-IT outsourcing firms & $0.4116^{\circledast \circledast}$ & 0.0061 & 0.0000 \\
\hline
\end{tabular}

Note: Changes in $\ln$ (labor productivity) due to IT outsourcing: ${ }^{\circledast}$ Firms with IT outsourcing and parameter vector with IT outsourcing compared to the situation if they had not outsourced their IT, i.e. parameter vector without IT outsourcing plus the respective selectivity terms. ${ }^{\circledast} \circledast$ Firms without IT outsourcing and parameter vector without IT outsourcing compared to the situation if they had outsourced their IT, i.e. parameter vector with IT outsourcing plus the respective selectivity terms.

Source: ZEW ICT-survey 2004 and own calculations. 
Table 12: Differences in unconditional $\ln ($ labor productivity)

\begin{tabular}{lccc}
\hline & $\begin{array}{c}\text { Mean } \\
\text { difference }\end{array}$ & $\begin{array}{c}\text { Std. } \\
\text { Err. }\end{array}$ & $\begin{array}{c}p- \\
\text { value }\end{array}$ \\
\hline IT outsourcing firms & $0.6528^{\circledast}$ & 0.0075 & 0.0000 \\
non-IT outsourcing firms & $0.6241^{\circledast \circledast}$ & 0.0061 & 0.0000 \\
\hline
\end{tabular}

Note: Changes in $\ln \left(\right.$ labor productivity) due to IT outsourcing: ${ }^{\circledast}$ Firms with IT outsourcing and parameter vector with IT outsourcing compared to the situation if they had not outsourced their IT, i.e. parameter vector without IT outsourcing. ${ }_{\circledast}^{\circledast} \circledast$ Firms without IT outsourcing and parameter vector without IT outsourcing compared to the situation if they had outsourced their IT, i.e. parameter vector with IT outsourcing.

Source: ZEW ICT-survey 2004 and own calculations. 
Table 13: Employment growth estimation results - first stage

\begin{tabular}{|c|c|c|c|c|}
\hline \multirow{2}{*}{$\begin{array}{l}\text { Dependent variable: } \\
\text { IT outsourcing (in 2000) }\end{array}$} & \multicolumn{2}{|c|}{ Spec. (I) } & \multicolumn{2}{|c|}{ Spec. (II) } \\
\hline & Coeff. & Std. Err. & Coeff. & Std. Err. \\
\hline $\ln$ (labor) & 0.0072 & 0.0537 & -0.0008 & 0.0686 \\
\hline $\ln (\text { labor })^{2}$ & -0.0065 & 0.0058 & -0.0043 & 0.0075 \\
\hline university degree & -0.0008 & 0.0010 & -0.0002 & 0.0013 \\
\hline vocational education & 0.0008 & 0.0008 & 0.0003 & 0.0010 \\
\hline East Germany & 0.0216 & 0.0402 & 0.0072 & 0.0474 \\
\hline firm age $(\leq 3$ years $)$ & - & - & 0.0481 & 0.0615 \\
\hline firm age $(3<$ years $\leq 7)$ & - & - & 0.0438 & 0.0509 \\
\hline IT applications $(0-8)$ & - & - & $0.0955^{* *}$ & 0.0479 \\
\hline IT applications (13-15) & - & - & $-0.1172^{* *}$ & 0.0477 \\
\hline$\triangle$ standard wages $(99-03)$ & - & - & 0.0283 & 0.0328 \\
\hline share of computer workers & - & - & -0.0007 & 0.0008 \\
\hline$\triangle$ share of comp. workers $(00-04)$ & - & - & 0.0001 & 0.0001 \\
\hline$\triangle$ IT specialists $(00-04)$ & - & - & $0.0469^{* *}$ & 0.0210 \\
\hline foreign subsidiary & - & - & $0.0984^{*}$ & 0.0557 \\
\hline export share & - & - & -0.0002 & 0.0009 \\
\hline consumer goods & 0.0621 & 0.0771 & 0.0181 & 0.0924 \\
\hline chemical industry & 0.0340 & 0.0808 & -0.0598 & 0.0980 \\
\hline other raw materials & 0.0841 & 0.0730 & -0.0154 & 0.0908 \\
\hline electrical engineering & $-0.1579 * *$ & 0.0729 & $-0.2377 * * *$ & 0.0903 \\
\hline precision instruments & -0.0256 & 0.0752 & -0.1048 & 0.0915 \\
\hline automobile & -0.0438 & 0.0763 & -0.0915 & 0.0980 \\
\hline wholesale trade & 0.1112 & 0.0860 & 0.0227 & 0.1058 \\
\hline retail trade & 0.0499 & 0.0876 & -0.1258 & 0.1121 \\
\hline transport and postal serv. & -0.0305 & 0.0783 & -0.0765 & 0.1201 \\
\hline banks and insurances & 0.0142 & 0.0833 & -0.0293 & 0.1049 \\
\hline technical services & -0.1334 & 0.0811 & $-0.2650^{* * *}$ & 0.1004 \\
\hline other business-related serv. & -0.0813 & 0.0784 & $-0.1663^{*}$ & 0.0965 \\
\hline Y2K consulting & $0.1488^{* * *}$ & 0.0330 & $0.1499^{* * *}$ & 0.0389 \\
\hline Constant & $0.4608^{* * *}$ & 0.1442 & 0.2554 & 0.3952 \\
\hline$R^{2}$ & \multicolumn{2}{|c|}{0.0939} & \multicolumn{2}{|c|}{0.1402} \\
\hline Number of observations & \multicolumn{2}{|c|}{910} & \multicolumn{2}{|c|}{659} \\
\hline
\end{tabular}

Note: $* * *$ and $* * *$ indicate significance at the $10 \%, 5 \%$ and $1 \%$ level respectively. Robust standard errors are shown in the Std. Err. columns. All variables refer to the year 1999 or 2000, except those variables inducing a rate of change (i.e. $\triangle$ standard wages, $\triangle$ computer workers, $\triangle$ IT specialists).

Source: ZEW ICT-survey 2000, 2004 and own calculations. 
Table 14: Employment growth estimation results - second stage

\begin{tabular}{|c|c|c|c|c|}
\hline \multirow{2}{*}{$\begin{array}{l}\text { Dependent variable: } \\
\text { employment growth (99-03) }\end{array}$} & \multicolumn{2}{|c|}{ Spec. (I) } & \multicolumn{2}{|c|}{ Spec. (II) } \\
\hline & Coeff. & Std. Dev. & Coeff. & Std. Dev. \\
\hline IT outsourcing & 0.5193 & 0.3848 & $0.8061^{* *}$ & 0.4061 \\
\hline $\ln$ (labor) & $0.4431^{* * *}$ & 0.1141 & $0.2636^{* *}$ & 0.1055 \\
\hline $\ln (\text { labor })^{2}$ & $-0.0561 * * *$ & 0.0137 & $-0.0354 * * *$ & 0.0129 \\
\hline university degree & $0.0057^{* * *}$ & 0.0022 & 0.0035 & 0.0025 \\
\hline vocational education & 0.0011 & 0.0014 & 0.0017 & 0.0017 \\
\hline East Germany & -0.0661 & 0.0562 & -0.0315 & 0.0632 \\
\hline firm age $(\leq 3$ years $)$ & - & - & -0.0678 & 0.1032 \\
\hline firm age $(3<$ years $\leq 7)$ & - & - & 0.0675 & 0.0813 \\
\hline IT applications $(0-8)$ & - & - & $-0.1895^{* *}$ & 0.0770 \\
\hline IT applications (13-15) & - & - & 0.1005 & 0.0937 \\
\hline$\triangle$ standard wages $(99-03)$ & - & - & $-0.0789^{*}$ & 0.0417 \\
\hline share of computer workers & - & - & $0.0022^{*}$ & 0.0013 \\
\hline$\triangle$ share of comp. workers $(00-04)$ & - & - & -0.0000 & 0.0002 \\
\hline$\triangle$ IT specialists $(00-04)$ & - & - & $0.3155^{* * *}$ & 0.0622 \\
\hline foreign subsidiary & - & - & 0.0286 & 0.1089 \\
\hline export share & - & - & -0.0016 & 0.0015 \\
\hline consumer goods & 0.0679 & 0.1264 & -0.0386 & 0.1428 \\
\hline chemical industry & 0.0928 & 0.1077 & 0.2032 & 0.1277 \\
\hline other raw materials & 0.0685 & 0.1060 & 0.1616 & 0.1338 \\
\hline electrical engineering & 0.1856 & 0.1309 & $0.3540^{* *}$ & 0.1723 \\
\hline precision instruments & 0.1181 & 0.1097 & 0.1964 & 0.1457 \\
\hline automobile & $0.1918^{*}$ & 0.1166 & 0.1608 & 0.1497 \\
\hline wholesale trade & 0.0136 & 0.1226 & -0.0394 & 0.1467 \\
\hline retail trade & -0.1166 & 0.1143 & -0.0245 & 0.1798 \\
\hline transport and postal serv. & 0.2097 & 0.1293 & 0.0483 & 0.1805 \\
\hline banks and insurances & 0.0605 & 0.1478 & -0.0057 & 0.1905 \\
\hline technical services & -0.1685 & 0.1615 & -0.0017 & 0.1992 \\
\hline other business-related serv. & -0.0479 & 0.1664 & -0.0026 & 0.1986 \\
\hline Constant & $-1.2644^{* * *}$ & 0.3390 & -0.3091 & 0.5344 \\
\hline Number of observations & \multicolumn{2}{|c|}{910} & \multicolumn{2}{|c|}{659} \\
\hline
\end{tabular}

Note: $* * *$ and $* * *$ indicate significance at the $10 \%, 5 \%$ and $1 \%$ level respectively. Robust standard errors are shown in the Std. Err. columns. All variables refer to the year 1999 or 2000, except those variables inducing a rate of change (i.e. $\triangle$ standard wages, $\triangle$ computer workers, $\triangle$ IT specialists).

Source: ZEW ICT-survey 2000, 2004 and own calculations. 
Table 15: Industry Classification

\begin{tabular}{|c|c|}
\hline Explanation & NACE \\
\hline \multicolumn{2}{|l|}{ consumer goods } \\
\hline manufacture of food products, beverages and tobacco & $15-16$ \\
\hline manufacture of textiles and textile products & $17-18$ \\
\hline manufacturing of leather and leather products & 19 \\
\hline manufacture of wood and wood products & 20 \\
\hline manufacturing of pulp, paper and paper products; publishing and printing & $21-22$ \\
\hline manufacturing n.e.c. & $36-37$ \\
\hline \multicolumn{2}{|l|}{ chemical industry } \\
\hline manufacture of coke, refined petroleum products and nuclear fuel & 23 \\
\hline manufacture of chemicals, chemical products and man-made fibres & 24 \\
\hline \multicolumn{2}{|l|}{ other raw materials } \\
\hline manufacture of rubber and plastic products & 25 \\
\hline manufacture of non-metallic mineral products & 26 \\
\hline manufacture of basic metal & 27 \\
\hline \multicolumn{2}{|l|}{ metal and machine construction } \\
\hline manufacture of fabricated metal products (except machinery and equipment) & 28 \\
\hline manufacture of machinery and equipment n.e.c. & 29 \\
\hline \multicolumn{2}{|l|}{ electrical engineering } \\
\hline manufacture of office machinery and computers & 30 \\
\hline manufacture of electrical machinery and apparatus n.e.c. & 31 \\
\hline manufacture of radio, television and communication equipment and apparatus & 32 \\
\hline \multicolumn{2}{|l|}{ precision instruments } \\
\hline manufacture of medical, precision and optical instruments, watches and clocks & 33 \\
\hline \multicolumn{2}{|l|}{ automobile } \\
\hline manufacturing of transport equipment & $34-35$ \\
\hline \multicolumn{2}{|l|}{ wholesale trade } \\
\hline wholesale trade and commission trade (except of motor vehicles and motorcycles) & 51 \\
\hline \multicolumn{2}{|l|}{ retail trade } \\
\hline sale, maintenance and repair of motor vehicles and motorcycles; retail sale of automotive fuel & 50 \\
\hline retail trade (except of motor vehicles and motorcycles), repair of personal and household goods & 52 \\
\hline \multicolumn{2}{|l|}{ transportation and postal services } \\
\hline land transport, transport via pipeline & 60 \\
\hline water transport & 61 \\
\hline air transport & 62 \\
\hline supporting and auxiliary transport activities; activities of travel agencies & 63 \\
\hline post and courier activities & 64.1 \\
\hline \multicolumn{2}{|l|}{ banks and insurances } \\
\hline financial intermediation & $65-67$ \\
\hline \multicolumn{2}{|l|}{ electronic processing and telecommunication } \\
\hline computer and related activities & 72 \\
\hline telecommunications & 64.2 \\
\hline \multicolumn{2}{|l|}{ technical services } \\
\hline research and development & 73 \\
\hline architectural and engineering activities and related technical consultancy & 74.2 \\
\hline technical testing and analysis & 74.3 \\
\hline \multicolumn{2}{|l|}{ other business-related services } \\
\hline real estate activities & 70 \\
\hline renting of machinery without operator and of personal and household goods & 71 \\
\hline $\begin{array}{l}\text { legal, accounting, book keeping and auditing activities; tax consultancy; market research and } \\
\text { public opinion pools; business and management consultancy; holdings }\end{array}$ & 74.1 \\
\hline advertising & 74.4 \\
\hline labor recruitment and provision of personnel & 74.5 \\
\hline investigation and security services & 74.6 \\
\hline industrial cleaning & 74.7 \\
\hline miscellaneous business activities n.e.c. & 74.8 \\
\hline sewage and refuse disposal, sanitation and similar activities & 90 \\
\hline
\end{tabular}




\section{References}

Abraham, K. and Taylor, S. (1996). Firms' Use of Outside Contractors: Theory and Evidence, Journal of Labor Economics 14(3): 394-424.

Amiti, M. and Wei, S. (2006). Service Offshoring and Productivity: Evidence from the United States, Working Paper 11926, NBER, Cambridge.

Antràs, P., Garicano, L. and Rossi-Hansberg, E. (2006). Offshoring in a Knowledge Economy, The Quarterly Journal of Economics 121(1): 31-77.

Antràs, P. and Helpman, E. (2004). Global Sourcing, Journal of Political Economy 112(3): 552-580.

Bertschek, I., Fryges, H. and Kaiser, U. (2006). B2B or Not to Be: Does B2B ECommerce Increase Labour Productivity?, International Journal of the Economics of Business 13(3): 387-405.

Bertschek, I. and Kaiser, U. (2004). Management Science 50(3): 394-404.

Bertschek, I. and Müller, M. (2006). Productivity Effects of IT-Outsourcing: Semiparametric Evidence for German Companies, in S. Sperrlich, W. Härdle and G. Adinli (eds), The Art of Semiparametrics, Physica-Verlag, Heidelberg, pp. 130-154.

Brynjolfsson, E. and Hitt, L. (1996). Paradox Lost? Firm-level Evidence on the Returns to Information Systems Spending, Management Science 42(4): 541-558.

Brynjolfsson, E. and Hitt, L. (2000). Beyond Computation: Information Technology, Organizational Transformation and Business Performance, Journal of Economic Perspectives 14(4): $23-48$.

Brynjolfsson, E. and Hitt, L. (2003). Computing Productivity: Firm-Level Evidence, The Review of Economics and Statistics 85(4): 793-808.

Chandler, A. (1962). Strategy and Structure, MIT Press, Cambridge, MA.

Christensen, C. and Rosenbloom, R. (1995). Explaining the Attacker's Advantage: Technological Paradigms, Organizational Dynamics, and the Value Network, Research Policy 24(2): 233-257.

Coase, R. (1937). The Nature of the Firm, Economica 4(16): 386-405. 
Dibbern, J., Goles, T., Hirschheim, R. and Jayatilaka, B. (2004). Information Systems Outsourcing: A Survey and Analysis of the Literature, The DATA BASE for Advances in Information Systems 35(4): 6-102.

Fixler, D. and Siegel, D. (1999). Outsourcing and Productivity Growth in Services, Structural Change and Economic Dynamics 10: 177-194.

Fuglie, K. and Bosch, D. (1995). Economic and Environmental Implications of Soil Nitrogen Testing: A Switching-Regression Analysis, American Journal of Agricultural Economics 77(4): 891-900.

Girma, S. and Görg, H. (2004). Outsourcing, Foreign Ownership, and Productivity: Evidence from UK Establishment-level Data, Review of International Economics 12(5): 817832.

Gordon, R. (2000). Does the "New Economy" Measure up to the Great Inventions of the Past?, Journal of Economic Perspectives 14.

Greenan, N. and Mairesse, J. (2000). Computers and Productivity in France: Some Evidence, Economics of Innovation \& New Technology 9(3): 275-315.

Görg, H. and Hanley, A. (2003). International Outsourcing and Productivity: Evidence from Plant Level Data, Research Paper 2003-20, The University of Nottingham.

Görg, H. and Hanley, A. (2004). Does Outsourcing Increase Profitability?, Discussion Paper 1372, IZA, Bonn.

Görg, H. and Hanley, A. (2005). International Outsourcing and Productivity: Evidence from the Irish Electronics Industry, North American Journal of Economics and Finance 16(2): 255-269.

Görg, H., Hanley, A. and Strobl, E. (2005). Productivity Effects of International Outsourcing: Evidence from Plant Level Data, Working paper, The University of Nottingham.

Grossman, G. and Helpman, E. (2002). Outsourcing in a Global Economy, Working Paper 8728, NBER, Cambridge.

Görzig, B. and Stephan, A. (2002). Outsourcing and Firm-level Performance, Discussion Paper 309, DIW, Berlin. 
Hempell, T. (2005). What's Spurious, What's Real? Measuring the Productivity Impacts of ICT at the Firm-Level, Empirical Economics 30: 427-464.

Heshmati, A. (2003). Productivity Growth, Efficiency and Outsourcing in Manufacturing and Service Industries, Journal of Economic Surveys 17(1): 79-112.

Jensen, M. and Meckling, W. (1976). Theory of the Firm: Managerial Behavior, Agency Cost and Ownership Structure, Journal of Financial Economics 3.

Jorgenson, D. (2001). Information Technology and the U.S. Economy, American Economic Review 91(1): 1-32.

Jorgenson, D., Ho, M. and Stiroh, K. (2004). Will the U.S. Productivity Resurgence Continue?, Federal Reserve Bank of New York - Current Issues in Economics and Finance 10.

Lee, L. (1978). Unionism and Wage Rates: A Simultaneous Equation Model with Qualitative and Limited Dependent Variables, International Economic Review 19(2): 415-433.

Loh, L. and Venkatraman, N. (1992). Determinants of Information Technology Outsourcing: A Cross-Sectional Analysis, Journal of Management Information Systems 9(1): 724.

Lokshin, M. and Sajaia, Z. (2004). Maximum Likehood Estimation of Endogenous Switching Regression Models, The Stata Journal 4(3): 282-289.

Maddala, G. (1983). Limited-Dependent and Qualitative Variables in Econometrics, Econometric Society Monographs, Cambridge University Press, Cambridge.

Markusen, J. (1995). The Boundaries of Multinational Enterprises and the Theory of International Trade, Journal of Economic Perspective 9(2): 169-189.

Miles, R. and Snow, C. (1978). Strategy and Structure, McGraw-Hill, New York, NY.

OECD (2001). OECD Manual - Measurement of Capital Stocks, Consumption of Fixed Capital and Capital Services, Manual, Organisation for Economic Co-Operation and Development, Paris, France.

Oliner, S. and Sichel, D. (2000). The Resurgence of Growth in the Late 1990s: Is Information Technology the Story?, Journal of Economic Perspectives 14(4): 3-22. 
Oliner, S. and Sichel, D. (2002). Information Technology and Productivity: Where Are We Now and Where Are We Going?, Economic Review 87(3): 15-44.

Olsen, K. (2006). Productivity Impacts of Offshoring and Outsourcing: A Review, OECD Science, Technology and Industry Working Paper 2006/1, OECD.

Porter, M. (1985). Competitive Advantage: Creating and Sustaining Superior Performance, Free Press, New York, NY.

Quinn, J. (1980). Strategies for Change: Logical Incrementalism, Richard D. Irwin, Homewood, IL.

Schreyer, P. and Pilat, D. (2001). Measuring Productivity, OECD Economic Studies 33(2001/2): 127-170.

Siegel, D. and Griliches, Z. (1992). Purchased Services, Outsourcing, Computers, and Productivity in Manufacturing, in Z. Griliches (ed.), Output Measurement in the Service Sectors, Univiversity of Chicago Press, Chicago, IL, pp. 429-460.

Stiroh, K. (2002). Information Technology and the U.S. Productivity Revival: What Do the Industry Data Say?, American Economic Review 92(5): 1559-1576.

ten Raa, T. and Wolff, E. (2001). Outsourcing of Services and the Productivity Recovery in U.S. Manufacturing in the 1980s and 1990s, Journal of Productivity Analysis 16: 149165.

Williamson, O. (1975). Markets and Hierarchies, Analysis and Antitrust Implications: A Study in the Economics of Internal Organization, Free Press, New York, NY.

Williamson, O. (1981). The Economics of Organization: The Transaction Cost Approach, American Journal of Sociology 87.

Williamson, O. (1985). The Economic Institutions of Capitalism: Firms, Markets, Relational Contracting, Free Press, New York, NY.

ZEW (2005). Internet bestimmt den Geschäftsalltag, ICT-Report, May 2005, ZEW, Mannheim.

ZEW (2007). Internetwirtschaft weiter auf dem Vormarsch, ICT-Report, September 2007, ZEW, Mannheim. 